\title{
Dawid Ledwoń
}

Uniwersytet Śląski w Katowicach

ORCID: 0000-0003-0075-9212

\section{Obrazy, funkcje i znaczenie kobiet w Apokalipsie Jana}

\begin{abstract}
Abstrakt: Do grona głównych bohaterów Janowej Apokalipsy należą kobiety. Ich obrazy, funkcje i znaczenie w tekście wizjonera z Patmos stanowią przedmiot niniejszego studium przeprowadzonego w ujęciu synchronicznym. Autor artykułu wykazuje, że horyzont egzegetycznych dociekań, oprócz występujących w Księdze Objawienia rzeczowników үuvń (kobieta, żona) oraz vú $\mu \varphi \eta$ (panna młoda, oblubienica), poszerza użycie skontrastowanych elementów symboliki kobiecej i metaforyki małżeńskiej. Popularnym motywom ze styku judaizmu i świata grecko-rzymskiego Jan nadał nowe znaczenie. Budują one obraz upersonifikowanego Kościoła, który walczy z upostaciowionym złem i triumfuje jako Oblubienica Baranka.
\end{abstract}

Słowa kluczowe: Apokalipsa Jana, metafora, symbolika, kobiety, obraz, studia nad płcią, teologia feministyczna

grona bohaterek Apokalipsy św. Jana największą uwagę eg-
zegetów przykuwają dwie, silnie kontrastujące ${ }^{1}$ ze sobą posta-
cie - Kobiety obleczonej w słońce (Ap 12) oraz Wielkiej Nierządnicy
(Ap 17-18). Natomiast pomija się niekiedy znaczenie pozostałych

1 Operowanie kontrastem należy do podstawowych cech proroczego dzieła Jana (por. M. Wojciechowski, Apokalipsa, 59) i jest jednym z narzędzi budowania napięcia w nacechowanej epizodycznością narracji Apokalipsy. 
kobiecych figur ${ }^{2}$ (Jezabel $^{3}$ czy nowego Jeruzalem) ${ }^{4}$ i symboli. Choć wskazane dysproporcje w naukowym dyskursie nie mają znamion dyskryminacji, to jednak niedowartościowanie obecnych w Apokalipsie motywów kobiecych budzi częściowo słuszne zastrzeżenia na gruncie biblijnej teologii feministycznej ${ }^{5}$. Powierzchowna lub wybiórcza analiza Janowego proroctwa utrudnia bowiem zebranie

2 J.E. Bruns, „The Contrasted Women”, 459 za godne uwagi uznaje trzy indywidualne przypadki, które mają wymiar symboliczny lub realny, a dotyczą Jezabel $(2,20)$ oraz kobiet $\mathrm{z}$ rozdziałów dwunastego i siedemnastego. Jednak spośród wymienionych postaci autor artykułu wybiera dwie ostatnie, wysuwając argument, że ich tożsamość nie budzi wątpliwości. Trudno jednak zgodzić się z tak arbitralnym stanowiskiem. Nie znajduje ono bowiem uzasadnienia w historii interpretacji dwóch wielkich kobiecych obrazów z Apokalipsy. Wystarczy przytoczyć tylko niektóre tytuły współczesne i późniejsze kanadyjskiemu bibliście: B.J. Le Frois, The Woman Clothed with the Sun; L. Stefaniak, „Mulier amicta sole”, 262-283; L. Stefaniak, Interpretacja 12 rozdzialu Apokalipsyśw. Jana; P. Prigent, Apocalypse 12 czy cytowane przez C.H. Dyer, „The Identity of Babylon”, 434 opracowania: M.C. Tenney, Interpreting Revelation; R.H. Mounce, The Book of Revelation oraz artykuł G. Biguzziego, „Is the Babylon”, 371-386. Na problem interpretacji Wielkiej Nierządnicy (Ap 17 i 18) w pismach reformatorów wskazuje również P. Nowakowski, „Kobiecy symbol apokaliptyczny”, 401-402. Niezrozumiałe wydaje się też pominięcie przez wspomnianego J.E. Brunsa w analizie postaci Jezabel z 2,20 oraz Oblubienicy Baranka z rozdziału dwudziestego pierwszego, argumentowane tym, że postać pierwszej z wymienionych jest nieistotna (,irrelevant" - sic!), a druga nie została przez Jana opisana jako kobieta, choć nazywana jest Oblubienicą (sic! - zob. Ap 21,2: „,przygotowana jak oblubienica ozdobiona dla męża swego"). Przedstawione braki w opracowaniu tematu uzupełnia dopiero analiza M.J. Selvidge poświęcona Jezabel (Ap 2), Niewieście obleczonej w słońce (Ap 12), seksualnej sile kobiet (Ap 14), Babilonii jako Wielkiej Prostytutce (Ap 17), Wielkiej Babilonii (Ap 18). W swoich badaniach autorka pomija jednak obecny w Ap 21 obraz Niewiasty, argumentując to ambiwalentnością określającego ją terminu vó $\varphi \varphi \eta$. Zob. M.J. Selvidge, „Powerful and Powerless”, 159, przyp. 8.

3 W przywoływanej literaturze obcojęzycznej, w ślad za BH, egzegeci posługują się brzmieniem „Jezebel”.

4 Wśród opracowań, gdzie pomija się niektóre kobiece figury w Apokalipsie, można wymienić: J.E. Bruns, „The Contrasted Women”, 459-463; W.H. Shea, „The Parallel”, 37-54; M.J. Selvidge, „Powerful and Powerless”, 157-167; P. Thimmes, „Women Reading Women”, 128-144; A.V. Rocha, „Entre la fragilidad y el poder”, 95-104. Na tle wskazanych publikacji pozytywnie wyróżnia się pogłębione studium z dziedziny antropologii biblijnej: U. Vanni, L'uomo dell'Apocalisse, 101-141.

5 Zob. E. Tamez, „Feminist Biblical Studies”, 41. 
elementów istotnych zarówno dla kompozycji kobiecych obrazów, ich prezentacji, jak też oceny znaczenia i funkcji wspomnianych postaci w tekście, który z tego względu budzi zainteresowanie tzw. Gender Studies ${ }^{6}$. Wyłonione pod wpływem drugiej fali feminizmu badania nad społeczno-kulturową tożsamością płci wykazują bowiem szczególną wrażliwość na sposób postrzegania kobiet oraz ich roli w społeczeństwie, wysuwając postulat przełamania determinujących je stereotypów, zwłaszcza o charakterze patriarchalnym ${ }^{7}$. Podnoszone na gruncie teologii feministycznej względem Janowej Apokalipsy coraz śmielsze zarzuty o mizoginizm ${ }^{8}$ zasługują na krytyczną uwagę. Wymaga ona ponownej analizy obrazu obecnych w dziele wizjonera z Patmos kobiecych postaci, jak też związanej z nimi symboliki i małżeńskiej metaforyki ${ }^{9}$, które obficie korzystają ze starotestamentowych wzorców ${ }^{10}$ i nawiązują do znanych w kulturze helleńskiej

6 Powstałe i rozwijane w wyniku drugiej fali feminizmu badania nad płcią kulturową już po trzech dekadach zaczęto uznawać za dominujące w naukach historycznych. Zob. J. Økland, „In publicum procurrendi”, 127. Spośród krytycznych względem Apokalipsy publikacji, które odpowiadają podejściu Gender Studies należy wymienić: T. Pippin, Death and Desire; T. Pippin, Apocalyptic Bodies; T. Pippin, J.M. Clark, „Revelation/Apocalypse”, 753-768; A.-J. Levine, M.M. Robbins (red.), Feminist Companion to the Apocalypse, 1-2.

7 H.J. Wood, „Gender Inequality”, 1-2.

8 M. Johnson-DeBaufre (,Texts and Readers”, 231), jako przykład krytyki przywołuje monografię E. Castelli, Imitating Paul, ale wypada jeszcze wymienić: A.Y. Collins, „Persecution and Vengeance”, 729-748; A.Y. Collins, Crisis and Catharsis; M.J. Selvidge, „Reflections on Violence”, 274-285; G.C. Streete, The Strange Woman. Bardzo krytyczna ocena Apokalipsy w przywołanych opracowaniach spotkała się jednak z merytoryczną odpowiedzią D.L. Barra, ,Towards an Ethical Reading”, 358-373. Por. A. Ipsen, Sex Working, 170, przyp. 3; S.E. Hylen, „Metaphor Matters”, 778, przyp. 3.

9 Dobre opracowanie stanu badań nad małżeńską metaforyką w Apokalipsie przedstawia L.R. Huber, Like a Bride, 1-44. Godne uwagi są także opracowania: L. Pedroli, „Le «Lettere alle sette Chiese»”, 87-101; L. Pedroli, Dal fidanzamento alla nuzialità escatologica.

10 Spośród wszystkich ksiąg Nowego Testamentu Apokalipsa zawiera najwięcej odniesień do pierwszej części Biblii chrześcijańskiej. Tej osobliwości literackiej i teologicznej Janowego Objawienia sporo uwagi poświęca G.K. Beale, The Book of Revelation, 76-99. 
motywów ${ }^{11}$. Wskazanie odniesienia literackie i teologiczne skłaniają do odpowiedzi na szereg pytań.

Czy wyłaniające się z chrystocentrycznej i udramatyzowanej przez Jana narracji ${ }^{12}$ wyobrażenia kobiet - realistyczno-symboliczne (Jezabel) i symboliczne (Niewiasty obleczonej w słońce, Wielkiej Nierządnicy - Babilonii, stolicy - i niebieskiego Jeruzalem - Oblubienicy Baranka) można uznać za rozbudowaną kontynuację znanej ze Starego Testamentu typologii oraz mitycznych figur? ${ }^{13} \mathrm{Czy}$ może autor Apokalipsy nadał nowe znaczenie popularnym motywom ze styku judaizmu i świata grecko-rzymskiego, by podporządkować je zbawczemu przesłaniu świadectwa, które głosi? ${ }^{14}$ Jak ocenić postawy, które bohaterowie Apokalipsy przyjmują wobec kobiecych postaci? Czy wspomnianych postaw nie determinują uprzedzenia ze względu na płeć? Wreszcie, jakie jest znaczenie przywołanych obrazów kobiet w Apokalipsie i jaką funkcję pełnią one w odniesieniu do jej adresatów? Innymi słowy: jaki wpływ na wartość tego profetycznego dzieła miałoby pozbawienie go kobiecych postaci, a także związanej z nimi symboliki i małżeńskiej metaforyki?

Odpowiedzi na przedstawione pytania można udzielić na drodze pogłębionego studium egzegetycznego w podejściu synchronicznym. Nie ignorując historii, bada ono tekst w jego ostatecznej, to znaczy

11 Zdaniem M. Wojciechowskiego wpływ grecki na Apokalipsę nie był bezpośredni. Jej autor mógł korzystać z wzorów przyjętych w judaizmie, choć - jak słusznie zaznacza egzegeta z Olsztyna - w Janowych wizjach nie brakuje obrazów zaczerpniętych z mitologii, a nie poświadczonych w judaizmie. Zob. M. Wojciechowski, Wpływy greckie w Biblii, 332; por. M. Wojciechowski, „Wpływy greckie w Apokalipsie", 116-117.

12 J.S. Duvall (The Heart of Revelation, 11) posługuje się określeniem „Divine Drama of Revelation". Trzeba jednak pamiętać, że użyty w odniesieniu do Apokalipsy Jana termin „dramat” ma jedynie znaczenie niegenologiczne. Nie oznacza bowiem (mimo niektórych cech: możliwe do wyróżnienia sceny, budowa napięcia w rozwijającej się akcji, której bohaterowie są zantagonizowani, występowanie monologów, dialogów, pieśni czy elementów absurdu) gatunku Janowego tekstu, a jedynie oddaje charakter relacjonowanych w nim wydarzeń.

13 Zob. T. Pippin, Apocalyptic Bodies, 1, 3 oraz P.G.R. de Villiers, „The Violence of Nonviolence", 198.

14 Por. R.H. Charles, A Critical and Exegetical Commentary on Revelation, cviii. 
kanonicznej postaci, a za punkt wyjścia przyjmuje perspektywę wiary. Tak zdefiniowane podejście zapewnia dotarcie do poziomu teologicznego tekstu i ukazanie możliwie całościowych obrazów kobiet w Apokalipsie Jana. W realizacji tego celu i rozwiązaniu zauważonych problemów służy najpierw precyzyjne ustalenie obszaru badań. Determinuje go występowanie w księdze terminów yuví (kobieta, żona) oraz vú $\mu \varphi \eta$ (panna młoda, oblubienica).

Pierwszy z wymienionych rzeczowników występuje w Apokalipsie dziewiętnaście razy. Pięć pojedynczych wzmianek dotyczy kolejno: Jezabel $(2,20)$, porównania włosów szarańczy $(9,8)$, dziewictwa naśladowców Baranka $(14,4)$, wreszcie Małżonki Baranka $(19,7 ; 21,9)$, nazwanej Jego Oblubienicą $(21,9)$. Najwięcej, bo aż osiem

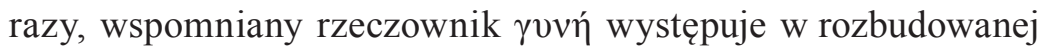
wizji z rozdziału dwunastego, która rozpoczyna się pojawieniem wielkiego znaku na niebie - Niewiasty przyobleczonej w słońce, $\mathrm{z}$ księżycem pod stopami i wieńcem $\mathrm{z}$ dwunastu gwiazd na głowie $(12,1.4 .6 .13 .14 .15 .16 .17)$. Blok sześciu kolejnych wzmianek znajduje się w rozdziale siedemnastym Apokalipsy, gdzie Jan przedstawia kobietę zasiadającą na szkarłatnym potworze (17,3.4.6.7.9.18). Natomiast drugi z przywołanych wcześniej terminów - vú $\mu \varphi \eta$ - oprócz 21,9, występuje w spisanym przez proroka z Patmos Objawieniu jeszcze trzykrotnie. Po raz pierwszy w 18,23, gdzie stanowi element złowieszczej zapowiedzi upadku wielkiej stolicy - Babilonii, w której nie będzie słychać głosu oblubieńca i oblubienicy ${ }^{15}$. Po raz drugi motyw panny młodej występuje w wizji nowego nieba i nowej ziemi. Wzmiankowana tam postać jest wprost identyfikowana ze Świętym Miastem Jeruzalem (21,2; por. 3,12). Wreszcie po raz trzeci mowa o niej w epilogu Apokalipsy, gdzie przyzywając Jezusa, wspólnie z Duchem zwraca się także do zbiorowego adresata Janowego Objawienia z bezpośrednią zachętą: „Przyjdź!” $(22,17)^{16}$. Ze względu na charakter wymienionych odniesień w Apokalipsie można je podzielić

15 Przestrogę z Ap 18,23 można uznać za analogię wypowiedzi z Jr 7,34; 16,$9 ; 25,10$ i Ba 2,23, które dotyczą miast judzkich, Jerozolimy oraz Judy. Jednak w przeciwieństwie do Babilonii - jako Wielkiej Nierządnicy z Janowej Apokalipsy wyrocznia Boga dla Jerozolimy u Jeremiasza zawiera też zapowiedź odmiany losu miasta dotkniętego karą (Jr 33,10-11).

16 D. Ledwoń, Apokalipsa, 15. 
na realistyczno-symboliczne i symboliczne ${ }^{17}$. Zaproponowana klasyfikacja determinuje etapy dalszej analizy, która pozwoli ustalić funkcję i znaczenie wyłaniających się z Janowego tekstu kobiecych obrazów.

\section{Wzmianki o charakterze realistyczno-symbolicznym}

Pierwszą grupę odniesień cechuje z jednej strony ich życiowy realizm, a z drugiej symbolizm. Rzeczywiste rysy posiada wzmiankowana w liście do Kościoła w Tiatyrze postać Jezabel $(2,20)$. Naturalnym elementem są także przyrównane do kobiecych włosy szarańczy (9,8a). Realizm cechuje także wzmianka dotycząca kobiet, z którymi nie współżyli naśladowcy Baranka $(14,4)$. Wreszcie, rzeczywisty wydaje się także głos oblubieńca i oblubienicy $(18,23)$. Nie ulega jednak wątpliwości, że wszystkie wymienione odniesienia w ich bezpośrednim i metaforycznym kontekście mają także znaczenie symboliczne. Warto zbadać jakie jest jego przesłanie, by móc zrozumieć, co ono mówi na temat kobiet, jaki kształtuje ich obraz w Apokalipsie i czemu on służy.

\subsection{Jezabel $(2,20)$}

Imię pierwszej wzmiankowanej w Apokalipsie kobiety jest kryptonimem osoby, która przez swoją wpływową pozycję w Tiatyrze miała możliwość swobodnego oddziaływania na wspólnotę lokalnego Kościoła ${ }^{18}$. Warto zauważyć, że postawione względem kobiety zarzuty głoszenia fałszywej nauki oraz zwodzenia do uprawiania

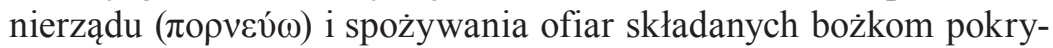
wają się z oskarżeniami, które Jezus kieruje względem działających w Efezie i Pergamonie nikolaitów $(2,6.15)$ oraz trzymających się nauki Balaama i bałwochwalczych praktyk Balaka $(2,14)$. Przede wszystkim jednak imię owej kobiety czyni wyraźną aluzję do żyjącej w IX w. przed Chr. i pochodzącej z Sydonu małżonki króla

17 U. Vanni (L'uomo dell'Apocalisse, 102) proponuje mniej precyzyjny podział na realistyczne i symboliczne.

18 D.E. Aune, Revelation 1-5, 203. 
izraelskiego Achaba. Jej historię w Starym Testamencie zawierają dwie Księgi Królewskie ${ }^{19}$.

W świetle wypowiedzi narratora pierwszej z nich, córka Etbaala stała się powodem religijnego odstępstwa syna Omriego. Za sprawą Jezabel, Achab nie tylko powielił grzechy swoich poprzedników, zwłaszcza Jeroboama $(22,53)^{20}$, ale nadto zaczął służyć bóstwu Sydończyków - Baalowi (1 Krl 16,31; 18,18; 21,20.25[LXX: 20,20.25]), którego semickie imię oznacza „pan”, „właściciel” lub „mąż”. Świątynia z ołtarzem i aszerą wzniesiona przez króla w stolicy Samarii na jego cześć (1 Krl 16,31-32) stała się instytucjonalnym narzędziem szerzenia w narodzie bałwochwalczego kultu fenickiego bóstwa wiatru, burz i płodności $(21,22)$, które - zgodnie z wyobrażeniami starożytnych - miało umierać w czasie suszy i powracać do życia w porze deszczu ${ }^{21}$. Na kartach historii biblijnego Izraela Jezabel zapisuje się również licznymi zbrodniami. Autor Pierwszej Księgi Królewskiej przypomina dokonywaną z polecenia królowej eksterminację proroków Pana (1 Krl 18,4.13; por. 2 Krl 9,7), prześladowanie Eliasza $(19,2)$ i sprokurowany proces Nabota, zakończony mordem sądowym fałszywie obwinionego, a następnie bezprawnym zagarnięciem jego winnicy (21,5-16). Z kolei w Drugiej Księdze Królewskiej namaszczony na króla nad Izraelem Jehu wypomina wobec

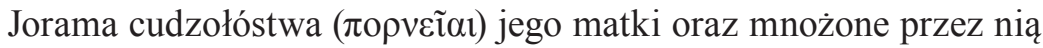
trucizny ( $(\alpha ́ \rho \mu \alpha \kappa \alpha)(2 \operatorname{Krl~9,22),~czemu~kres~-~według~zapowiedzi~}$ Eliasza - położy okrutna śmierć królowej (1 Krl 21,23[LXX: 20,23]; 2 Krl 9,10.32-37).

Przytoczone dane biograficzne pozwalają stwierdzić, że biblijna postać małżonki Achaba, do której aluzję czyni wzmiankowana w Apokalipsie Jezabel, stanowi radykalne zaprzeczenie ideału kobiety jako oblubienicy (Rdz 2,20.23-24; Prz 31,10-31; Syr 26,2-3.14),

19 Na dwadzieścia dwie wzmianki w Starym Testamencie o Jezabel aż piętnaście przypada na Pierwszą Księgę Królewską (16,31; 18,4.13.19; 19,1.2[×2]; 20,5.7.11.14.15.23.25; 22,53), zaś pozostałych siedem znajduje się w Drugiej Księdze Królewskiej (9,7.10.22.30.36.37).

20 Sformułowane względem Achaba zarzuty dotyczą utrwalania przez monarchę religijnego i politycznego rozbicia biblijnego Izraela oraz złamania zawartego w Pwt 7,3-4 zakazu zawierania małżeństw mieszanych z poganami.

21 W. Tyloch, „Religie Fenicji i Syrii”, 123. 
stając się pułapką dla władcy i samego narodu (por. Koh 7,26), przede wszystkim zaś symbolicznym przeciwnikiem Boga. Nie ulega wątpliwości, że w ocenie Chrystusa fałszywa prorokini $(\pi \rho \circ \varphi \tilde{\eta} \tau \iota)^{22}$ z Tiatyry powiela ten antyprzykład życia. Zamiast prowadzić Kościół do zjednoczenia z Jego Oblubieńcem, który w świetle Janowej relacji ma oczy przenikliwe jak płomień ognia i przypomina Syna Człowieczego z wizji proroka Daniela (Dn 10,6), apokaliptyczna Jezabel zwodzi sługi Jezusa (Ap 2,20). Jej działanie, wyrażone za pomocą czasownika $\pi \lambda \alpha v \alpha ́ \omega$, posiada lokalny zasięg, ale wpisuje się w szeroko zakrojoną inicjatywę smoka, określanego starodawnym wężem, diabłem i szatanem $(12,9 ; 20,3.8 .10)$, odpowiada szkodliwej aktywności drugiego potwora $(13,14)$ - którym jest fałszywy prorok $(19,20)$ - i zwodzącej wszystkie narody Babilonii $(18,23)^{23}$.

W przeciwieństwie do wymienionych protagonistów poszczególnych wizji danych Janowi, fałszywa prorokini z Tiatyry otrzymuje od Chrystusa czas do nawrócenia $(2,21)$. Łoże ${ }^{24}$, na które owa kobieta

22 Odpowiadający terminowi $\pi \rho \circ \varphi \tilde{\eta} \tau ı \varsigma$ w BH rzeczownik נביאה po raz pierwszy określa siostrę Aarona - Miriam, za którą w tańcu podążają inne kobiety (Wj 15,20). Po wejściu do Kanaanu funkcję prorokini sprawuje w Izraelu Debora, żona Lappidota $(\mathrm{Sdz} 4,4)$. Noszony przez nią zaszczytny tytuł przysługuje później Chuldzie, żonie Szalluma (2 Krl 22,14; 2 Krn 34,22) oraz żonie Izajasza, która przez poczęcie i zrodzenie mu syna staje się częścią prorockiego znaku (Iz 8,3). Natomiast do grona fałszywych proroków zaliczona zostaje Noadia, której podstępne działanie miało zniechęcić Nehemiasza do odbudowy murów Jerozolimy (Ne 6,14).

23 Por. C. Vander Stichele, „Re-membering the Whore”, 113. Z kolei E.J. Hamori (Women's Divination, 215-216) łączy występki Jezabel z wróżbiarstwem, wskazując na analogię pomiędzy bohaterką Apokalipsy a żoną Achaba. Amerykańska biblistka z Union Theological Seminary błędnie powołuje się jednak na dane zawarte w $1 \mathrm{Krl}$. W rzeczywistości wzmianka o licznych czarach Izebel występuje dopiero w 2 Krl 9,22. Z kolei T. Pippin, odnosząc się do roli jaką w Apokalipsie odgrywa fałszywa prorokini, zgodnie z właściwą dla feminizmu hermeneutyką wysuwa błędną opinię, że ,złożona i niejednoznaczna postać Jezabel służy w Biblii za archetyp prostytutki-wiedźmy-królowej w mizoginistycznych przedstawieniach kobiet” (zob. T. Pippin, „Jezebel Re-Vamped”, 222). Przywołanej tezie przeczą dane biblijne: zarówno znikoma liczba wzmianek dotyczących Jezebel, jak też nie mniej krytyczne oceny licznego grona męskich antybohaterów historii zbawienia, których losy przedstawiają autorzy natchnieni.

${ }^{24} \mathrm{~W}$ greckim tekście Apokalipsy brak wyraźnego dopowiedzenia - jak

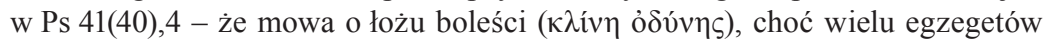


zostaje rzucona z powodu swego uporu w złym, staje się dla niej narzędziem kary, podobnie jak zapowiedziany ucisk dla dopuszczających się cudzołóstwa $(2,22)$ i śmierć należącego do Jezabel potomstwa $(2,23)$. Są to konsekwencje poznania głębin Szatana (por. Ap 2,24) i przebywania w bliskości jego tronu $(2,13)$.

\subsection{Włosy szarańczy $(9,8 a)$}

Druga wzmianka dotycząca kobiet w Apokalipsie występuje w wizji wydarzeń, które rozgrywają się po brzmieniu piątej trąby i otwarciu studni czeluści. Z wydobywającego się z niej dymu wychodzi szarańcza o mocy skorpiona. W opisie jej wyglądu, na tle użytych przez Jana zoomorfizmów, uwagę zwracają dwa porównania. Zawierają one elementy antropomorficzne: podobne do ludzkich oblicza (9,7b) oraz włosy $(9,8 \mathrm{a})$. Te ostatnie określa posiadający funkcję przydawki dopełniaczowej termin yuví. Nie służy on deprecjonowaniu kobiet, ale oddaniu zbytniej długości włosów, którą w przypadku mężczyzn różnie oceniano. W czasach Starego Testamentu długie włosy nosili wojownicy (Sdz 16,13.19; 1 Sm 14,25-26) oraz składający ślub nazireatu (Lb 6,1-21; Sdz 13,5.7; 16,17; $1 \mathrm{Sm} \mathrm{1,11).} \mathrm{Sam} \mathrm{autor} \mathrm{Dziejów}$ Apostolskich wspomina o ścięciu włosów przez Pawła w Kenchrach, zgodnie ze złożonym przez niego przyrzeczeniem $(18,18)$. Jednak z wypowiedzi Apostoła w 1 Kor 11,14 można już wywnioskować, że noszenie przez mężczyzn długich włosów uważano za hańbiący przejaw zniewieścienia, bądź za oznakę barbarzyńskiego pochodzenia $^{25}$. Ta ostatnia cecha najbardziej odpowiada apokaliptycznej szarańczy ${ }^{26}$. Jej groźny wygląd i szkodliwa dla ludzi aktywność

właśnie za takie je uważa. Zdaniem P. Thimmes („Teaching and Beguiling”, 74, przyp. 24) powodem podobnych interpretacji jest zseksualizowany język całej perykopy i wynikająca stąd intencja uczonych, by zbytnio nie rozbudzać nim wyobraźni.

25 D.E. Aune, Revelation 6-16, 532.

26 U. Vanni (L'uomo dell'Apocalisse, 106), odnosząc się do wzmiankowanych w Ap 9,8a kobiecych włosów, przyjmuje zakorzenioną w tradycji wczesnochrześcijańskiej interpretację, że są one wyrazem uwodzicielskich umiejętności kobiet. Jednakże bezpośredni kontekst poczynionej przez Jana wzmianki nie uprawdopodobnia takiego poglądu. 
symbolicznie ucieleśniają zarówno wszystkie niebezpieczeństwa czasów wędrówki biblijnego Izraela przez pustynię (Pwt 8,15), jak też nieszczęścia, które spadają na grzeszników (Syr 39,30) lub które oni sami uosabiają (Ez 2,6). Ponadto z grona autorów starotestamentowych tylko Jezus, syn Syracha, przyrównuje wybór złej żony do złapania w garść skorpiona (Syr 26,7), czyniąc to jadowite stworzenie negatywnym elementem metaforyki kobiecej i małżeńskiej.

\subsection{Dziewiczy naśladowcy Baranka $(14,4 a)$}

Intersującym komponentem literackiego obrazu kobiet w Apokalipsie Jana jest wzmianka o tłumie wykupionych z ziemi $(14,3)$, którzy nie oddali się plamiącej relacji z kobietami i są dziewicami $(14,4 a)$. Z pozoru szorstka wypowiedź wizjonera z Patmos nie wynika z pogardy dla małżeństwa ani z chęci marginalizowania kobiet czy ze strachu przed nimi ${ }^{27}$. Figuratywny język wizjonera $\mathrm{z}$ Patmos domaga się metaforycznej interpretacji zarówno użytego w tekście zwrotu

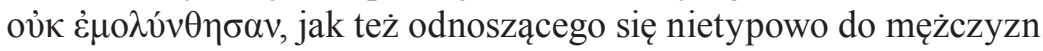
rzeczownika $\pi \alpha \rho \theta \varepsilon \dot{\varepsilon} \nu^{28}$. Przemawia za tym kilka faktów.

Po pierwsze, do ukazania relacji pomiędzy Chrystusem a Kościołem, autor Apokalipsy korzysta z kluczowej dla Starego Testamentu metafory oblubieńczej. Po drugie, sto czterdzieści cztery tysiące opieczętowanych symbolicznie wyraża ogół zbawionych - nowy Izrael, a nie wąską grupę ludzi. Jest zatem rzeczą niemożliwą, by wszyscy oni byli celibatariuszami ${ }^{29}$. Nawet jeśli Jan docenia dziewictwo ${ }^{30}$, którego wartość potwierdza wcześniej Mt 19,12; 1 Kor 1,7,1.7, to z pewnością nie postrzega tego ideału jako obowiązku czy warunku koniecznego do zbawienia. Po trzecie, najbliższy kontekst perykopy, a więc wydarzenia przedstawione w Ap 13 oraz następujące po niej w 14,6-13, sugerują, że we wspomnianym „,nie splamieniu się” chodzi

27 Literalnie i tym samym błędnie interpretują Ap 14,4a przedstawicielki teologii feministycznej: A.Y. Collins (Crisis and Catharsis, 159-160) oraz T. Pippin (Death and Desire, 50). Niestety nie są to głosy odosobnione, na co zresztą zwraca uwagę G.R. Osborne (Revelation, 528).

28 J.L. Resseguie, The Revelation of John, 195.

29 S.S. The Revelation, 356.

30 D. Ledwoń, Apokalipsa, 115. 
raczej o odrzucenie idolatrii ${ }^{31}$. Zresztą prorocy często zrównują bałwochwalstwo narodu wybranego z cudzołóstwem ${ }^{32}$. Nie można też wykluczyć, że użyty przez Jana zwrot nawiązuje do starotestamentowego wymogu zachowania czystości rytualnej, w tym czasowej abstynencji seksualnej. Wystarczy wspomnieć zalecenie skierowane do ludu przed objawieniem się Boga na Synaju (Wj 19,14-15) czy

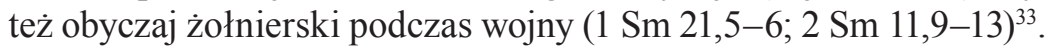

W świetle przywołanej tradycji biblijnej dziewictwo opieczętowanych, którzy wiernie podążają ( $\dot{\alpha} \kappa o \lambda o v \theta \dot{\varepsilon} \omega)$ za Chrystusem, są

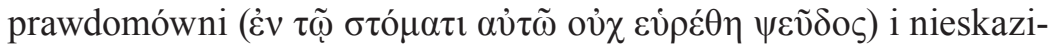
telni ( $(\mu \omega \mu \mathrm{s})$, oznacza całkowitą i trwałą wolność od wszelkiego moralnego zepsucia. Właśnie ta cecha decyduje o wartości wyku-

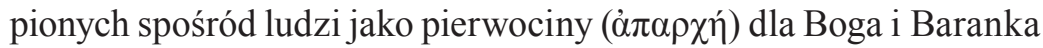
(14,4b-5), który łączy w sobie dwa biblijne ideały: wypróbowanego w cierpieniu sługi Pańskiego (Iz 53,9) oraz nieskazitelnego kapłana (Ml 2,6). Dzięki temu, w wyłącznej relacji do Boga i Baranka, życie Jego naśladowców - oddzielonych jakby do świętej posługi ${ }^{34}$ - zyskuje wartość koszernej ofiary ${ }^{35}$. Nie jest ona ekspiacją ani nie służy przebłaganiu, lecz prowadzi do unikalnego w swoim rodzaju uwielbienia Stwórcy. Śpiewanej Mu przez nich nowej pieśni nikt bowiem nie może się nauczyć (Ap 14,2-3; por. 7,10-11.15), co jeszcze bardziej podkreśla kontrast pomiędzy dziewiczym orszakiem Baranka jako

31 D. Kotecki (Jezus a Bóg Izraela, 393) przyjmuje tę interpretację jako jedyną możliwą, odrzucając pozostałe, które dotyczą pochwały wstrzemięźliwości seksualnej czy celibatu.

32 Prorocy przekazują orędzie dotyczące niewierności narodu jako niewiasty oddającej się (a nie oddawanej stręczycielsko) w objęcia obcych mężczyzn (Jr 2,20.25; 3,1; Oz 2,4.6-7; 3,1). Jej życie Izajasz splata nierozdzielnie z dziejami Jerozolimy, nazywanej Córą Syjońską (Iz 4,4) oraz winnicą Pana Zastępów $(5,7)$, pytając wpierw z niedowierzaniem o to, kiedy stała się nierządnicą $(1,21)$. Z kolei Ezechiel przypomina cudzołóstwa sióstr: Oholi - Samarii i Oholiby - Jerozolimy (Ez 23,1-46). Natomiast małżeństwo Ozeasza z kobietą nierządną $(\mathrm{Oz} 1,2)$, podobnie jak całe jego życie rodzinne, stają się wymownym symbolem wiernej i cierpliwej miłości Boga do ludu jako swej małżonki (Oz 2,18-19.21-22; 3,2-3; por. Iz 49,18). Zob. także B.K. Blount, Revelation, 268, przyp. 19.

33 B.M. Fanning (Revelation, 391) podaje też dla porównania 1 QM 7:3-7.

34 M.E. Boring, Apocalisse, 201-202.

35 R.L. Thomas, Revelation 8-22, 198. 
nowym ludem kapłańskim a tymi, którzy podążają zgubną drogą Babilonii, Jezabel czy Balaama ${ }^{36}$.

Wizja opieczętowanych jest pozytywna. W swym zewnętrznym wyglądzie przypominają wiernych Jezusowi z Kościoła w Sardach $(3,4)$ i są podobni do przyodzianej w szaty z czystego lnu Oblubienicy Baranka $(19,7-8)^{37}$. Charakteryzując liczne grono wykupionych spośród ludzi, Jan posługuje się dobrze znanym adresatom orędzia językiem tradycji biblijnej. Jej literackim i teologicznym tworzywem jest w tym przypadku oparta na kontraście cnót i wad kobieca metaforyka. Korzystając z niej, autor nie stygmatyzuje kobiet, ale ukazuje ich społeczne oddziaływanie.

\subsection{Głos oblubieńca i oblubienicy $(18,23)$}

Czwarte realistyczne odniesienie do świata kobiet, które współtworzy ich obraz w wizjonerskim dziele Jana, znajduje się w obwieszczeniu skutków Bożego wyroku na Wielki Babilon (18,21-24). Nieodwołalność tych ostatnich uwydatnia w wypowiedzi anioła sześciokrotne użycie podwójnego przeczenia oủ $\mu$ í $(18,21.22[\times 3] .23[\times 2])$. Posługując się przywołaną formułą, Jan po raz kolejny sięga po elementy obrazowania, które są właściwe dla starotestamentowej metaforyki oblubieńczej i życia społecznego. Dlatego w apokaliptycznej Babilonii, zgodnie z wyrocznią zawartą w Jr 25,10, mają zamilknąć dźwięki radości charakterystyczne dla uroczystości weselnej, jak głos harfiarzy, śpiewaków, fletnistów i trębaczy (Ap 18,22a; por. 1 Mch 9,39.41; Jr 7,34; 51,55; Ba 2,23), wreszcie głos obojga narzeczonych $(18,23 b)$. Ich brak potęguje jeszcze zapowiedź ustania wszelkiej działalności artystycznej (18,22b) i rzemieślniczej (18,22c), które cechują aglomerację miejską. Znakiem wyniszczenia tętniącego w niej życia mają stać się milczące żarna $(18,22 \mathrm{c}$; Iz 47,2) oraz wygasłe lampy domostw (Ap 18,23; por. Prz 31,18; Mt 25,1.3.7.8). Wreszcie mowę anioła ogłaszającego skutki wyroku na Wielką Nierządnicę wieńczy przypomnienie jej win, które zdawały się wołać do Boga o pomstę: „bo twoi kupcy byli wielmożami ziemi, bo trucicielstwem

36 Por. H. Stenström, „They have not defiled themselves with women”, 41.

37 J.L. Resseguie, The Revelation of John, 195-196. 
twoim omamione zostały narody i w tobie krew proroków i świętych oraz wszystkich zamordowanych na ziemi" (18,23c-24; por. 6,10; 17,2; 18,3). Z przytoczonych skutków upadku wielkiej stolicy ustanie głosu oblubieńca i oblubienicy wydaje się najbardziej istotne. Przepadło bowiem to, co wyraża harmonię relacji dwojga ludzi opartą na wzajemnej miłości. Ona jest powodem weselnej muzyki i pogodnej codzienności wyrażonych terkotem żaren - poruszanych zwykle przez kobiety (zob. Wj 11,5; Iz 47,2; Mt 24,41) - i zapalanym przez nie światłem lampy (zob. Prz 31,18). Dostatek ani pokój nie będą jednak domeną wielkiej stolicy, symbolicznie przedstawionej przez Jana w obrazie Wielkiej Nierządnicy. Ich spełnienie ukazuje dopiero wizja Nowego Jeruzalem - nieskazitelnej Oblubienicy Baranka.

\section{Odniesienia o charakterze symbolicznym}

Do drugiej grupy wspomnianych odniesień w Apokalipsie należy zaliczyć pozytywne i negatywne wyobrażenia z gruntu nierzeczywistych postaci kobiecych, które posiadają wymiar indywidualny i kolektywny ${ }^{38}$. W prezentacji wspomnianych figur Jan posługuje się głównie opisem sytuacyjnym i wyglądu, odzwierciedlając ich duchowe cechy, a także podlegające ocenie postawy. Wyobrażenia autora Apokalipsy czerpią z tradycji starotestamentowej i grecko-rzymskiej mitologii ${ }^{39}$, są częścią wydarzeń osadzonych w bliżej nieokreślonym czasie, dzięki czemu nabierają one uniwersalnego charakteru - dotyczą pierwszych adresatów Janowego orędzia i przyszłych jego adresatów, zanurzonych w tej samej eschatologicznej perspektywie ostatecznego sądu nad światem. Fascynujące jest to, że dla jej zobrazowania autor Apokalipsy posługuje się symbolicznymi postaciami o wyraźnie kobiecych rysach: brzemiennej Niewiasty obleczonej w słońce (12,1-18), Wielkiej Nierządnicy - Babilonu (17,118,24), Oblubienicy i Małżonki Baranka - Niebieskiego Jeruzalem

38 D. Neufeld, „Under the Cover of Clothing”, 71.

39 Słusznie zauważa M. Wojciechowski (Wpływy greckie w Biblii, 336), że w twórczości Jana mity dostarczyły jedynie materiału literackiego, a nie inspiracji na poziomie treści. Autor Apokalipsy wykorzystał tylko pewne obrazy (motywy), by - przetwarzając je - powiedzieć coś zupełnie innego i ostatecznie wyprzeć mit. 
(19,7-9; 21,1-22,5), wreszcie Oblubienicy przyzywającej wraz Duchem Jezusa $(22,17)$. Warto przyjrzeć się każdej z osobna, dokonując analizy wymienionych figur $\mathrm{w}$ podyktowanym przez Jana porządku chronologicznym, by zobaczyć, co proporcjonalnie wnoszą do literackiej i teologicznej kompozycji obrazów kobiet w Apokalipsie.

\subsection{Niewiasta obleczona w słońce $(12,1-18)$}

Pierwsza z wymienionych w Apokalipsie symboliczna postać kobieca, obleczona w słońce, mająca księżyc pod stopami i wieniec z dwunastu gwiazd na głowie, posiada atrybuty wiecznej chwały Boga i Jego zastępów (por. Pnp 6,10), jest uosobieniem nowego Izraela (Rdz 37,9) $)^{40}$, dzieł prawdziwej Mądrości (Mdr 7,29), kobiecego piękna i dobroci (Syr 26,15-16), nowym stworzeniem dla oznaczenia dnia i oddzielenia go od ciemności, jak powołane przez Boga do istnienia ciała niebieskie ( $\mathrm{Rdz} 1,14-19)$. Fakt, iż stanowią one integralną część apokaliptycznego znaku brzemiennej Niewiasty, wskazuje na jej przynależność do nieba, a pośrednio zdradza naturę wydanego przez nią na świat Syna, który ma paść narody żelazną laską $(12,5)^{41}$. Sugestywny obraz cierpiącej bóle rodzenia Matki i jej Syna nawiązuje do starotestamentowych proroctw ${ }^{42}$. Odnoszą się one do Izraela i jego zbawczej misji pośród narodów (Iz 26,17-27,1) oraz obiecanego Mesjasza, którego Jahwe ustanawia nad nimi królem i pasterzem (Ps 2,8-9; Iz 7,14; Ez 34,23; Mi 5,2-5). O ile w biblijnych proroctwach Pomazaniec Pański jest raczej narzędziem zbawczego działania Jahwe, które On sam przypieczętuje ukaraniem węża i smoka

40 Por. A.Y. Collins, „Feminine Symbolism”, 124.

41 M.J. Selvidge („Powerful and Powerless”, 163) błędnie charakteryzuje kobiecą postać z dwunastego rozdziału Apokalipsy, nazywając ją bezsilną boginią i biernym narzędziem, które samo z siebie nie może uczynić dobra ani zmienić projektu historii. Taka interpretacja amerykańskiej biblistki ignoruje symbolikę wyglądu Niewiasty. Wieniec z gwiazd jest symbolem zwycięstwa, podobnie jak księżyc umieszczony pod jej stopami, który oznacza panowanie nad zmiennością i czasem (por. B. Urbanek, Apokalipsa, 158). Niewiasta nie jest słońcem, ale została nim przyobleczona, zatem przynależy do sfery boskiej, a nie jest bóstwem.

42 Zdaniem M. Bednarza („Niewiasta obleczona w Słońce”, 26) Stary Testament stanowi klucz do zrozumienia omawianego obrazu Niewiasty. 
(Iz 27,1), o tyle Dziecię z wizji Jana ma swoje miejsce u Boga i Jego tronu, dokąd zostaje uniesione (Ap 12,5).

Chociaż w Apokalipsie brak eksplicytnych wzmianek dotyczących Maryi, a postać obleczonej w słońce Niewiasty pierwotnie pojmowano eklezjologicznie ${ }^{43}$, to dokonywana w tradycji Kościoła pod wpływem Ewangelii relektura tekstu, pozwala przyjąć także mariologiczną interpretację przedstawionej w nim kobiety ${ }^{44}$. Jawi się ona jako antytyp starotestamentowej Ewy ${ }^{45}$ i zarazem prototyp - wzór doskonałej kobiety ${ }^{46}$; jest Matką Mesjasza, Arką Przymierza (Ap 11,9) i obrazem pielgrzymującego Kościoła.

Niewiasta obleczona w słońce nie cierpi z tego powodu, że nie wydała zbawczego ducha (Iz 26,18) ani nie kryje się w swoich komnatach w dniu Bożego sądu nad mieszkańcami ziemi jak jej starotestamentowa figura (26,20-21). Kobieta znajduje schronienie na pustyni. Ta z kolei, nawiązując do historii biblijnego Izraela, pozostaje miejscem ucieczki (Ap 12,6.14; por. Wj 16,32; Ps 136[135],16; Jr 2,6; Ez 2,10; Dz 7,32) i wejścia w oblubieńczą relację z Panem (Jr 2,2; 31,2; Oz 2,16), który wyposażając kobietę w skrzydła, chroni swą opatrznością nowy lud Boży - Kościół (Ap 12,14; por. Wj 19,4;

${ }^{43}$ M. Rosik, „Mariologia”, 288. W odniesieniu do eklezjologicznej interpretacji Niewiasty z dwunastego rozdziału Apokalipsy M. Wojciechowski (Apokalipsa, 270) przywołuje szereg najwcześniejszych opinii na ten temat: Hipolita, Metodego z Olimpu, Tykoniusza, Wiktoryna, Hieronima, Augustyna, Cezarego z Arles, Prymazjusza, Andrzeja z Cezarei oraz Bedy.

${ }^{44}$ Mariologiczna interpretacja Niewiasty z Apokalipsy sięga twórczości żyjącego w V w. Quodvuldetusa (CCSL 60.349), ale rozwija się intensywnie dopiero od XIX w. (por. C.R. Koester, Revelation, 527) i znajduje odzwierciedlenie w wypowiedzi Nauczycielskiego Urzędu Kościoła. Jan Paweł II w Redemptoris Mater nr 24 stwierdza wprost, że „Ta, która jako «łaski pełna» została wprowadzona w tajemnicę Chrystusa, by być Jego Matką, czyli Święta Boża Rodzicielką, przez Kościół pozostaje w tej tajemnicy jako owa «niewiasta», na którą wskazuje Księga Rodzaju $(3,15)$ u początku, Apokalipsa zaś u kresu dziejów zbawienia $(12,1)$ ”.

${ }^{45}$ Rozumienie Maryi jako antytypu biblijnej Ewy widoczne jest najpierw u Justyna w Dial. 100.5, a później u Ireneusza z Lyonu w Adv. Haer. 3,23.7; 4,40.3; 5,21.1. Por. D. Mastalska, „Maryja spełnieniem miłości Ojca”, 64. Szerzej na ten mariologii w pismach Ireneusza zob. B. Częsz, „Maryja”, 70-85.

${ }^{46}$ J. Chmiel, „Model kobiety w Biblii”, 258. 
Ps 55[54],7-8 ${ }^{47}$. Przynosi on światu Chrystusa pośród doczesnych cierpień i prześladowań ${ }^{48}$, a należący do niego, nazwani przez głos z nieba „naszymi braćmi”"49 $(12,10)$, zwyciężają dzięki krwi Baranka oraz słowu swojego świadectwa ( $\mu \alpha \rho \tau v \rho i ́ \alpha)$. Ich radykalizm polega na zaparciu się miłości do własnego życia ,,[aż] do śmierci” $(12,11)$, a dzięki temu na wyraźnym upodobnieniu do Jezusa. Jego świadectwo posiada zwalczane przez smoka pozostałe na ziemi potomstwo Niewiasty, określone w tekście Apokalipsy mianem „nasienia” $(\sigma \pi \varepsilon \dot{\varepsilon} \mu \alpha)$. Zachowuje ono przykazania Boga $(12,17)$ i jawi się jako potomstwo nowej Ewy, które zmiażdży głowę węża ( $\mathrm{Rdz} 3,15)$. Ten w tradycji biblijnej symbolizuje siły $z^{5}{ }^{50}$, królestwa wrogie Izraelowi (Iz 27,1; Jr 51,34; Ez 29,3; 32,2), a zwłaszcza Egipt, nazywany przez psalmistę i proroka Izajasza Rahabem ${ }^{51}$ (Ps 87[86],4; 89[88],11; Iz 30,7; 51,9).

Przywołany przez Jana motyw walki smoka z Niewiastą (12,4b.13.15-16), a następnie z jej potomstwem (12,17-18), posiada wyraźnie starotestamentowy rodowód, choć nie można zupełnie wykluczyć pośredniej inspiracji autora mityczną historią o prześladowanej przez Pytona tytanidzie Leto, której syn Apollo zgładził potężnego węża ${ }^{52}$. Dostrzegając podobieństwo motywów, należy podkreślić, że w proroczym dziele Jana mit stanowi tylko jedno

47 Paralelą dla wizji w Ap 12,14 jest również zawarty w Iz 31,5 obraz Boga osłaniającego i wyzwalającego Jeruzalem.

48 D. Ledwoń, Apokalipsa, 103.

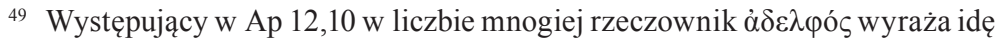
szeroko pojętego rodzeństwa w wierze, a zatem dotyczy braci i sióstr.

50 W Ap 12,15 siły zła wyraża woda wypuszczona z gardzieli Smoka w pogoni za Niewiastą (por. Lb 16,32-34; 26,10; Pwt 11,6).

51 W Księdze Hioba termin רהב oznacza upersonifikowaną siłę zła, pokonaną wraz ze swymi pomocnikami przez Boga (Hi 9,13; 26,12).

52 Ciekawe opracowanie na temat mitu o Latonie i różnic w przekazujących go tekstach źródłowych przedstawia J.E. Fontenrose (Python, 13-22). Za bezpodstawną jednak należy uznać hipotezę A.Y. Collins (The Combat Myth, 75-76), że Ap 12 jest fuzją mitu o Leto z tradycjami dotyczącymi egipskiej Izydy. Bliższa wydaje się argumentacja A.D. Pataki („A Non-combat Myth”, 270), cytującego L. Morrisa (The Book of Revelation, 151), że Jan nie jest kopistą niestrawnych pogańskich mitów i konsekwentnie też pogańskie religie nie zawierają klucza do interpretacji Apokalipsy, ponieważ ten zawiera się w Słowie Bożym. 
z wielu narzędzi wyrażania i interpretacji historii ludzkości ${ }^{53}$, która dzięki interwencji Boga staje się historią zbawienia. Batalia o jej finał ma wymiar kosmiczny, angażując niebo i ziemię jako arenę decydujących rozstrzygnięć, podyktowanych zwycięstwem żyjącego na wieki Baranka (Ap 1,18). Tylko dozgonnie wierni świadectwu Jezusa mają udział w Jego ostatecznym tryumfie $(2,10$; 12,11; por. 2 Tm 4,8; $\mathrm{Jk}$ 1,12). Ich postawa jest motywem obecnego w Ap 12,12 wezwania do radości nieba oraz jego mieszkańców, którzy w widzeniu Jana są uczestnikami liturgii przed tronem Boga i Barankiem $(4,1-5,14)$ oraz świadkami wejścia do chwały wielonarodowego tłumu zbawionych (7,9-17; 21,24), zapisanych w księdze życia (20,15; por. Iz 4,3) jako obywateli Świętego Miasta. Jego wizję w Apokalipsie poprzedza jednak obraz wielkiej stolicy jako personifikowanego antywzorca kobiety i matki.

\subsection{Wielka Nierządnica - Babilon $(17,1-18,24)$}

Miasto, nazwane przez jednego z siedmiu aniołów plag Wielką Nierządnicą, która zasiada nad wieloma wodami $(17,1)$, pełni rolę głównej antybohaterki rozgrywających się na ziemi apokaliptycznych wydarzeń. Są one - podobnie jak wspomniana postać kobieca przedmiotem Bożego wyroku ${ }^{54}(18,1-24)$, odpowiadającego skali jej moralnego zepsucia. Wielkość winy wyraża w tekście Janowej relacji poprzedzony rodzajnikiem przymiotnik $\mu \varepsilon \gamma \alpha ́ \lambda \eta$, a następnie informacja, że grzechy Babilonii narosły do nieba $(18,5)$. Miara ta odpowiada grzechom biblijnej poprzedniczki wielkiej stolicy (Jr 51,9),

53 M.E. Boring, Apocalisse, 182-183. Zdaniem biblisty z Brite Divinity School oraz Texas Christian University, „narracyjna chrystologia Apokalipsy jest relatywnie niemitologiczna, a nawet antymitologiczna. W całej narracji uwaga skupia się na Jezusie historycznym (zwłaszcza na Jego śmierci i zmartwychwstaniu) oraz obecnemu działaniu wywyższonego Chrystusa”. Zob. M.E. Boring, „Narrative Christology", 718.

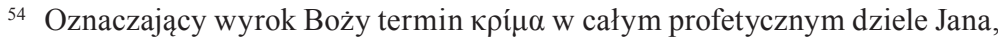
oprócz 17,1 występuje jeszcze dwukrotnie. W 18,20, jak za pierwszym razem, jego wydanie stanowi domenę Boga, z kolei w 20,4, posiadana przez Niego władza zostaje udzielona zasiadającym na tronach sędziom. Razem z męczennikami, którzy królują z Chrystusem, przynależą do tryumfującej społeczności zbawionych w niebie. 
choć nigdzie w Starym Testamencie Babilonia nie jest nazwana „nierządnicą”. Godny uwagi jest fakt, że przywołany epitet u proroków określa przede wszystkim Izraela (Jr 3,6-10; Ez 16,15-22; 23,1-49; Oz 4,12-13; 5,3), Jeruzalem (Iz 1,21), Tyr (Iz 23,15-17) i Niniwę $(\mathrm{Na} 3,4)^{55}$. Natomiast w Apokalipsie Jana omawiany tytuł rozwija znaczenie kryptonimu zdegenerowanej moralnie stolicy rzymskiego imperium $(17,18)^{56}$, brutalnie szerzącego bałwochwalcze kulty, łącznie $\mathrm{z}$ deifikowaniem panujących w nim cesarzy. Ponadto w Apokalipsie określenie „nierządnica” wyprzedza nazwanie miasta kobietą ${ }^{57}$ i przywołuje pamięć o złej sławie Sodomy i Gomory (Rdz 18,20; por. Iz 1,9; 13,19). Tym bardziej zasadne wydaje się w tekście nazwanie miasta z Janowej wizji „matką nierządnic ${ }^{58}$ i obrzydliwości ziemi” (Ap 17,5).

Ubrana w purpurę i szkarłat, przyozdobiona złotem, perłami i drogimi kamieniami oraz trzymająca złoty $\operatorname{puchar}^{59}$ nierządnica (17,4; por. 18,12) wyglądem nawiązuje do czczonej gorliwie w Azji Mniejszej bogini Romy ${ }^{60}$. Jej postać, zasiadająca pośród siedmiu pagórków miasta (por. 17,9), wraz z wężowatym wyobrażeniem boga Tybru, zdobiła rzymskie monety, bite niegdyś w azjatyckiej prowincji cesarstwa $^{61}$. Przywołany kolor szat nierządnicy, tożsamy z umaszczeniem

55 Por. S.D. Moore, Untold Tales, 127.

56 W 1 P 5,13 Babilon jest utożsamiany z Rzymem jako miejscem działalności Kościoła oraz Piotra wraz z towarzyszącym Apostołowi Markiem.

57 Por. K.E. Miller, „The Nuptial Eschatology”, 303. Fakt, że określenie ,nierządnica" wyprzedza nazwanie miasta kobietą ma znaczenie w kontekście krytycznych głosów środowisk feministycznych pod adresem Janowego proroctwa, któremu przypisują one rzekomo zakorzenioną w Starym Testamencie niechęć do kobiet. Podstawą potępienia Wielkiej Nierządnicy nie jest bowiem jej płeć, ale niemoralne czyny, których się nie wyrzekła, podobnie jak zwodząca Izraela biblijna Jezabel.

${ }_{58}$ Wzmiankowane w Ap 17,5 nierządnice są kryptonimem innych miast cesarstwa, zwłaszcza Azji Mniejszej, gdzie żywo szerzono imperialne kulty. Por. M. Wojciechowski, Apokalipsa, 328.

${ }_{59}$ Pełen obrzydliwości puchar z Ap 17,4 symbolizuje truciznę zgorszenia i stanie się powodem kary dla Babilonii, która od Boga otrzyma - jak dawniej grzeszne miasta - kielich Jego gniewu (Ap 16,19; por. Iz 51,17; Lm 4,21; Ez 23,31-33). Szerzej na temat tego wątku: B. Urbanek, „Metafory gniewu Bożego”, 256-260.

${ }^{60}$ D.E. Aune, Revelation 17-22, 925-928.

${ }^{61}$ M. Wojciechowski, Wplywy greckie w Biblii, 338-339. 
potwora, bardzo mocno kontrastuje z odzieniem brzemiennej Niewiasty $(12,1-2)$ i Oblubienicy Baranka $(19,7-8 ; 21,2)$. Purpura i szkarłat symbolizują nie tylko zamożność Wielkiej Nierządnicy, ale także jej władcze aspiracje sięgnięcia po królewską godność należną wyłącznie Chrystusowi ${ }^{62}$. Pijana krwią świętych i świadków Jezusa kobieta $(17,6)$ ma udział w czynach potwora wychodzącego z czeluści $(11,3)$ i smoka prześladującego Kościół (12,3-4.13-18), a także inspirującego swą mocą potwora, który wychodzi z morza $(13,1-4)$. Pełna bluźnierczych imion szkarłatna bestia o demonicznym pochodzeniu $^{63}$, mająca siedem głów i dziesięć rogów (17,3), jawi się jako parodia Boga i Chrystusa. W przeciwieństwie do Tego, który był, jest i przychodzi $(1,4.8 ; 4,8)$, żyje wiecznie $(1,18)$, jest początkiem i końcem $(21,6 ; 22,13)$, potwora cechuje efemeryczność: był, a go nie ma i znów przyjdzie $(17,8)$. Wyraźna niestałość charakteryzuje też panowanie sprzymierzonych z potworem królów $(17,12)$, którzy walcząc z Barankiem, w swej zagładzie podzielą los potwora i Wielkiej Babilonii (17,11.14.16), oglądanej przez Jana na pustyni $(17,3)$.

Ów bezludny obszar, w odróżnieniu od miejsca schronienia Niewiasty obleczonej w słońce $(12,6.14)^{64}$, ma tym razem negatywne znacznie. Nie jest już bowiem miejscem Bożej opieki ani czasu wchodzenia w oblubieńczą relację narodu z Panem (Ps 78[77],52; Jr 2,6; Oz 2,16-17). Wzmiankowana w Ap 17,3 pustynia jawi się jako miejsce sądu i wyniszczenia (por. Ps 106[105],26; Oz 2,5; Iz 21,1-2), które przedstawia mroczna wizja upadku Wielkiego Miasta (Ap 17,18; 18,2). Z kolei obraz nagiej i spustoszonej stolicy (Ap 17,16-18) zdradza inspiracje prorockimi wyroczniami przeciw Samarii, Jerozolimie

62 S.S. Smalley, The Revelation, 430.

63 Na pochodzenie szkarłatnego potwora, o którym mowa w Ap 17,8, wskazuje jego wyjście z czeluści.

${ }_{64}$ M.J. Selvidge („Powerful and Powerless”, 164, przyp. 30) pozostawia nierozstrzygniętą kwestię identyfikacji pustyni, pytając, czy jest ona tym samym miejscem, w którym ukryła się Niewiasta obleczona w słońce $(12,14)$. Z kolei w ocenie D.E. Aune (Revelation 17-22, 933) pustynia w 17,3 ma znaczenie pejoratywne. Zdaniem egzegety z Loyola University w Chicago, wzmianka o bezludnym miejscu występuje w kontraście do pozytywnej lokalizacji jaką w Apokalipsie jest wielka i wyniosła góra, z której uniesiony przez anioła Jan w zachwyceniu ogląda Święte Miasto Jeruzalem $(21,10)$. 
(Jr 13,26-27; Ez 16,39; 23,10.22-34) i Babilonowi (Ps 137[136],8-9), nazwanemu przez Izajasza „Dziewicą” i „Córą Chaldejską” (Iz 47,1.5). Jak ona, podobnie wielka stolica z Apokalipsy (Ap 18,2) - uważana za inicjatorkę rozpusty na ziemi ${ }^{65}$ - traci królewską pozycję i staje się wdową ${ }^{66}$ (Ap 17,7-8; por. Iz 47,1.8-9). Jednak w odróżnieniu od swej poprzedniczki (Jr 50,29), za okazaną pychę ma zostać ukarana podwójnie (Ap 18,6). Wskutek upadku, dotknięta plagami, śmiercią, smutkiem, głodem i ogniem (Ap 18,8; Syr 39,29-30), Wielka Babilonia zamienia się w kryjówkę dzikiego zwierzęcia i nieczystego ducha (Ap 18,2; por. Jr 25,12; 51,37).

Upersonifikowana stolica imperium jawi się jako antywzorzec kobiety i karykatura matki, która nie rodzi, ale sama wyniszcza ${ }^{67}$ i hańbiącym postępowaniem doprowadza do własnej zagłady, gdyż jej ciało zostaje pożarte $\mathrm{z}$ nienawiści ${ }^{68}$, spalone w ogniu przez przeciwników (Ap 17,16; 18,6-9) i opuszczone przez niedawnych stronników $(18,10.14 .17)^{69}$. Wielkie Miasto staje się w ten sposób znakiem degeneracji ludzkiej natury na płaszczyźnie osobowej i społecznej ${ }^{70}$, jawi się jako symbol zaprzepaszczenia wszystkiego, co cenne ${ }^{71}$. Ekonomiczny i cywilizacyjny upadek Babilonii, nad którym - jak nad upadkiem Tyru (Ez 27,30-34) - biadają czerpiący

65 M.J. Selvidge, „Powerful and Powerless”, 165.

66 Wdowieństwo, związane niejednokrotnie z utratą źródła utrzymania, jest w Biblii symbolem materialnego ubóstwa i trudnego położenia życiowego ( $R d z$ 38,11; Wj 22,21; Syr 35,14-15; Jr 15,8; Mk 12,42-43; Łk 12,3-5; 21,2-3). S.R. Smolarz (Covenant and the Metaphor, 272) wyraża pogląd, że Babilonia była wcześniej blisko Boga jako Jego żona i utożsamia ją wprost z Jerozolimą.

${ }_{67}$ M.J. Selvidge, „Powerful and Powerless”, 166.

68 T. Pippin (Apocalyptic Bodies, 96) zainspirowana twórczością kanadyjskiej pisarki M. Atwood, określa nawet Babilonię mianem „kobiety do zjedzenia”.

69 B.R. Rossing, The Choice Between Two Cities, 87-90; A. Ipsen, Sex Working, 171.

70 C. Doglio, Apocalisse, 178.

71 Zdaniem C. Vander Stichele („Re-membering the Whore”, 116) uznanie Wielkiej Nierządnicy z Apokalipsy jedynie za metaforę lub obraz zaciemnia relację między metaforą a rzeczywistością. W ocenie Profesor z Tilburg University, personifikacji nierządnicy - podobnie jak matki czy dziewicy - nie należy też sprowadzać do problemu płci, ale w każdej z kobiecych figur Apokalipsy widzieć wyraz strukturalnych problemów dotyczących rasy, klas czy imperialnych prześladowań. 
z niej niegodziwe zyski królowie ziemi, a także kupcy i handlarze niewolnikami (Ap 18,10.16.19), odsłania bardzo nietrwałe podstawy międzyludzkich relacji, które tworzą społeczną tkankę stolicy rzymskiego cesarstwa. Gdy do zstępującego od Boga Nowego Jeruzalem możni i narody wnoszą swe bogactwa $(21,24.26)$, Wielka Babilonia traci je (18,12-14.16), upodabniając się do biblijnej Sodomy, z której Bóg wzywa do ucieczki swój lud, aby nie miał on udziału w grzechach ani zniszczeniu potężnego miasta (Ap 18,4; por. Rdz 19,15-22). Wydany na nie wyrok staje się motywem zawierającego epimeryzm ${ }^{72}$ wezwania do radości. Pierwszym jego adresatem jest niebo jako miejsce przebywania Boga, następnie święci, apostołowie i wywodzący się z chrześcijańskich wspólnot prorocy $^{73}$ (Ap 18,20). Tło tej podniosłej zachęty stanowi zawarte w Biblii Hebrajskiej proroctwo Jeremiasza, w którym niebo i ziemia oraz wszystko, co w nich jest, mają wykrzyknąć z radości z powodu nadciągających na Babilon jego niszczycieli (Jr 51,48). W widzeniu Jana funkcję analogiczną do roli Serajasza z Księgi Jeremiasza pełni anioł (Ap 18,21; Jr 51,63-64). Wrzucony przez niego do morza wielki kamień, podobny rozmiarem do kamienia młyńskiego (por. Mt 18,6; Mk 9,42; Łk 17,2), wyraża w Apokalipsie definitywny sąd Boga nad gorszącym miastem, zapowiadając nieodwracalną zagładę stolicy, o czym rozstrzyga kategoryczne stwierdzenie: „i już jej nie odnajdą” $(18,21)$. Echa dramatycznego upadku Babilonii brzmią jeszcze w dziękczynieniu składanym Bogu przez mieszkańców nieba $(19,1-2)$, których anioł

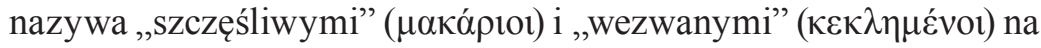
ucztę weselną Baranka $(19,9)$.

\subsection{Oblubienica i Małżonka Baranka - Niebieskie Jeruzalem (19,7-9; 21,1-22,5)}

Radość z królowania Boga $(19,6)$ i nadejścia weselnych godów Baranka (19,7-9) radykalnie odróżnia społeczność zbawionych od

72 Figura myśli, zwana w teorii literatury enumeracją lub wyliczeniem, polega na rozbiciu na części pewnej całości, która nie została wspomniana. Zob. E.W. Bullinger, Figures of Speech, 435.

73 Por. Dz 15,32; 1 Kor 12,28-29; 14,29.32.37; Ef 2,20; 3,5; 4,11; 2 P 3,2; Ap 22,9. 
mieszkańców ziemi, lamentujących nad zagładą wielkiej Nierządnicy (18,9-19). W jaskrawym kontraście do niej na scenę apokaliptycznych wydarzeń zostaje wprowadzona wspólnym głosem niebian inna symboliczna postać o kobiecych rysach, nazwana Małżonką Baranka (19,7). To zwięzłe określenie staje się kluczem do identyfikacji jeszcze bezimiennej figury ${ }^{74}$, której odzieniem są sprawiedliwe czyny świętych $(19,8)$. Tożsamość kobiecej postaci odsłania dopiero wizja zstępującego od Boga Świętego Miasta - Nowego Jeruzalem $(21,2.10)^{75}$, nazwanego tym razem przez anioła „Oblubienicą i Małżonką Baranka" $(21,9)$. Informacja o jej przygotowaniu $(\dot{\varepsilon} \tau o u \mu \alpha ́ \zeta \omega)^{76}$ jak dla męża $(21,2$; por. 19,7) znajduje rozwinięcie w szczegółowym opisie miasta mającego chwałę Boga (21,10b-22,5). Zdumiewa ono zarówno swym architektonicznym rozmachem (dwanaście bram; nieporównywalna powierzchnia miasta i wysokość jego murów), jak też wartością konstrukcyjnych elementów (bramy wykonane $\mathrm{z}$ pereł; mur miasta $\mathrm{z}$ jaspisu, a zabudowa oraz rynek wykonane z najczystszego złota; dwanaście warstw fundamentu murów miasta, zdobnych drogocennymi kamieniami o różnej barwie). Literackim tłem porównania, użytego przez Jana w 21,2 dla ich wyrażenia, są dwa starotestamentowe obrazy.

Pierwszy, bezpośrednio związany z metaforyką małżeńską, ukazuje Jerozolimę lub Izraela jako kogoś przystrojonego przez Boga

74 B.R. Rossing, The Choice Between Two Cities, 137.

75 Por. J. Fekkesa III, „His Bride”, 269. Zbliżona do apokaliptycznej idea nowego Jeruzalem znajduje się w Liście do Hebrajczyków. Jego autor przedstawia oczekiwane przez Abrahama miasto, którego architektem jest Bóg (11,10). Stanowi ono przestrzeń doświadczenia Go w zgromadzeniu świętych już przez udział w ziemskiej liturgii Kościoła (Hbr 12,22-23). Ponadto jest ono miastem poszukiwanym przez wierzących, którzy oczekują jego nadejścia $(13,14)$. Idea nowego Jeruzalem występuje też w Liście Pawła do Galatów, gdzie mowa o ,górnym Jeruzalem” $(4,27)$, które z kolei w Liście do Filipian Apostoł Narodów nazywa „niebieską ojczyzną” $(3,20)$ - z niej wyczekiwane jest przez wierzących przyjście Pana Jezusa Chrystusa.

76 Wzmiankowane w Ap 21,2 przygotowanie - a nie przystrojenie - jak słusznie zauważa H. Witczyk („Eklezjologia”, 207), posiada głębokie znaczenie teologiczne, ponieważ dotyczy inicjatywy planu zbawienia i jego realizacji. Trafnie zauważa też W. Popielewski (Alleluja!, 265), że w przygotowaniu Oblubienicy nie chodzi o jednorazową czynność, ale o cały proces, który zakończył się w momencie nadejścia godów. 
w szaty zbawienia i płaszcz sprawiedliwości, przyozdobionego zawojem (פאר) na wzór oblubieńca i klejnotami (כליה) jak oblubienica (Iz 61,10; por. Rdz 24,53). Drugi z kolei przedstawia Izraela oraz Syjon jako święte miejsce obecności Bożej chwały ${ }^{77}$. Wzmianki o kosztownościach i zawoju, oznaczającym w Wj 39,28 oraz Ez 44,18 kapłańską mitrę, czynią aluzję do izraelskiego kultu i przypominają o wybraniu narodu, którego Bóg ustanowił ludem świętym oraz królestwem kapłanów (Wj 19,6; por. Pwt 26,19; 28,9; Iz 62,12; 1 P 2,9), by pośród niego zamieszkać (Wj 25,8; 29,45-46; Lb 35,34; Pwt 7,21; Joz 3,10; Iz 12,6; So 3,17; Za 2,14). Tę ideę - za sprawą głosu dobiegającego od tronu - przywołuje w Apokalipsie obraz przybytku Boga z ludźmi (21,3), a wyraża go poprzedzony rodzajnikiem określonym

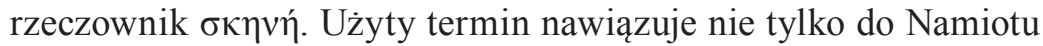
spotkania z czasów wędrówki biblijnego Izraela przez pustynię (Wj 25,1-31,11; 35,1-40,38), ale także do Izajaszowego proroctwa dotyczącego Jerozolimy jako bezpiecznej i stabilnej siedziby, miejsca sprawowania prawdziwego kultu (Iz 33,20; por. Mdr 9,7). Jego ośrodkiem w wizji Ezechiela jest odnowiona świątynia (40,1-43,17; 46,19-47,12), położona w mieście, otoczonym bramami, którego nazwa ma brzmieć: יהוה שמה - ,Pan [jest] tam” (Ez 48,35). W odróżnieniu od Ezechiela, sługa Jezusa - Jan - przedstawia to właśnie miasto jako rzeczywistość eschatologiczną, zstępującą z nieba od Boga, a nie ziemską budowlę przyszłości w postaci świątyni. Tą, zgodnie ze świadectwem wizjonera z Patmos, jest sam Bóg oraz Baranek $(21,22)$, zrównany z Nim jako źródło światła dla miasta (Ap 21,23; 22,5). Nie potrzebuje ono bowiem - zgodnie z proroctwem Trito-Izajasza - ani światła słońca, ani blasku księżyca (Iz 60,19-20), ponieważ wypełnione chwałą Boga (por. Iz 60,2), jako społeczność świętych, jaśnieje światłem lampy, którą jest Baranek ${ }^{78}$.

Apokaliptyczna wizja Nowej Jerozolimy odpowiada izajańskiej idei miasta jako Bożej Oblubienicy ${ }^{79}$, do której zmierzają narody,

77 G. Witaszek („Jerozolima”, 59) stwierdza, że święta przestrzeń Syjonu stała się jak matczyne łono. Egzegeta przywołuje w tym względzie wypowiedzi Deutero-Izajasza, który ukazuje Syjon podczas gdy rodzi (Iz 49,21; 54,1; 51,18), następnie nadaje imię $(48,2)$, wreszcie traci i odzyskuje swoje dzieci $(49,20 ; 51,18-20)$.

78 G.K. Beale, The Book of Revelation, 1093.

79 J. Fekkes III, „His Bride”, 270. 
a królowie przynoszą ogrom ziemskiego bogactwa (Iz 60,3-9.17; Ap 21,24-26). Stale otwarte bramy miasta (Iz 60,11; Ap 21,25) podkreślają uniwersalizm Bożej obietnicy zbawienia, zapowiedzianej w czasach Starego Testamentu, a urzeczywistnionej dzięki zwycięstwu Baranka. Pomimo wyraźnych nawiązań do kobiecej metaforyki, relacja Jana, dotycząca wizji Nowej Jerozolimy, pozbawiona jest znaczących antropomorfizmów, obecnych w poetyckim opisie miasta u Trito-Izajasza. Są tam nimi w pierwszej kolejności bezpośrednie zwroty, które oddają osobowy charakter Jeruzalem jako adresatki wypowiedzi Boga. Zachęca On bowiem miasto, by powstało i świeciło (Iz 60,1), następnie skłania je jako matkę, by podniosło oczy i spojrzało wokół na swoich synów i córki $(60,4)$, czemu ma towarzyszyć poruszenie serca i wielka radość $(60,5)$. Ze względu na Boga, przybywają do Jeruzalem i są na jego usługi okoliczne narody $(60,12-13)$. Wreszcie z ich oraz z królewskich piersi ma ono również ssać mleko, uznając Boga za swego Pana, Zbawcę, Wszechmocnego Jakuba i swego Odkupiciela $(60,16)$. W Jego oblicze mają się wpatrywać zgromadzeni przed tronem w widzeniu Jana (Ap 22,4).

Opisując wnętrze Świętego Miasta ${ }^{80}$, wizjoner z Patmos powraca do utrwalonych w proroctwie Ezechiela obrazów odnowionej świątyni $^{81}$. Ponieważ w Apokalipsie jest nią Bóg i Baranek, dlatego to od Ich tronu, a nie od progu przybytku (Ez 47,1), wypływa lśniąca jak kryształ rzeka wody życia (Ap 22,1), zaś nad jej brzegami owocują drzewa, przynoszące zdrowie narodom (Ez 47,12; Ap 22,2). Niebieskie Jeruzalem w Janowym widzeniu jawi się jako nowy rajski ogród $^{82}$, w którym władza nad drzewem życia ma należeć do tych, co płuczą swoje szaty $($ Ap 22,14). W przywołanej przez Jana wypowiedzi Jezusa, zostają oni nazwani szczęśliwymi ( $\mu \alpha \kappa \alpha ́ p ı$ ). Natomiast wyrażający dokonywaną przez nich czynność opłukiwania czasownik $\pi \lambda u ́ v \omega$, użyty w imiesłowie czynnym, kojarzy ją jednoznacznie z postępowaniem wielonarodowego tłumu przybyłych na

${ }^{80}$ U Izajasza nowe Jeruzalem ma być nazwane Miastem Pana i Syjonem Świętego Izraela (Iz 60,14b).

81 B.R. Rossing, The Choice Between Two Cities, 153.

${ }^{82}$ Zdaniem J.A. du Rand („The New Jerusalem”, 295) Nowe Jeruzalem jest ostatecznym wypełnieniem Edenu oraz świątyni. Podobnie uważa M. Karczewski (Reinterpretacja, 103). 
niebieską liturgię, o których jeden ze starców w niebie wydaje świadectwo, że wybieli swe szaty we krwi Baranka $(7,14)$. Jedni i drudzy, to znaczy opłukujący szaty i przyodziani w nie już przed tronem Wszechmogącego, należą do tej samej, zbudowanej na fundamencie apostolskim społeczności. Wkraczają do niej-przez szeroko otwarte bramy obietnic pierwszego Izraela $(21,12.24-26)$ - kolejne rzesze wiernych (kobiet i mężczyzn), którzy mając udział w zwycięstwie Baranka, jako część nowego stworzenia, cieszą się udziałem w jego Bożym synostwie (por. 21,5.7) ${ }^{83}$. O ile Niewiasta obleczona w słońce jest figurą Kościoła-Matki na ziemi i zapowiedzią niebiańskiego Jeruzalem, o tyle Święte Miasto stanowi już obraz Małżonki Baranka i Matki zbawionych. Przyjmuje ona do domu Boga spragnionych życia, udręczonych trudami doczesności, a jednocześnie jest źródłem uzdrowienia dla wszystkich narodów.

\subsection{Oblubienica, która mówi wraz z Duchem $(22,17)$}

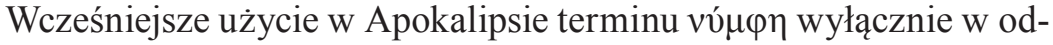
niesieniu do Nowego Jeruzalem pozwala na identyfikację kobiecej postaci z epilogu Janowego dzieła ze społecznością, która już tworzy Święte Miasto i ma w nim przystęp do źródła oraz drzewa życia $\left(22,17\right.$ c.19 ${ }^{84}$. Trzeba jednak zwrócić uwagę, że wypowiadana przez Ducha i Oblubienicę zachęta „Przyjdź!” powtarza się w wołaniu tego, kto słyszy, ale także odczytuje słowa proroctwa $(22,17-20$; por. 1,3$)$ i nie należy jeszcze do grona mieszkańców niebieskiego Jeruzalem.

Adresatem obydwu przywołanych wypowiedzi jest - podobnie jak w 22,20 - sam Jezus, ale mogą być nimi także wszyscy spragnieni wody życia $(22,17)$, wszyscy, do których jest kierowane Proroctwo Janowe; wreszcie każdy, kto przychodzi z wielkiego ucisku i ma udział w królestwie Jezusa $(1,9 ; 7,14.17)^{85}$. Pragnienie, by ono nastało także na ziemi, w Janowym widzeniu wyraża już wołanie czterech istot żyjących (6,1.3.5.7). Ich błagalne „Przyjdź!” inicjuje pojawienie się czterech jeźdźców, którzy symbolicznie zapowiadają wydarzenia

\footnotetext{
83 Por. G.K. Beale, The Book of Revelation, 1058.

84 Zob. M. Wojciechowski, Apokalipsa, 398.

85 Por. D.E. Aune, Revelation 17-22, 1228.
} 
poprzedzające paruzję Chrystusa. Należą do nich: zwycięstwo głoszonej Ewangelii $(6,2)$, niepokój i wojny $(6,4)$, nieurodzaj $(6,6)$, wreszcie głód i zaraza $(6,8)$. Wymienione wydarzenia, wraz z dotykającymi mieszkańców ziemi plagami (16,8-21), stanowią wezwanie do nawrócenia i wyrażają oczekiwaną reakcję Boga na cierpienie zadawane wierzącym $(6,10)$. Błagalne „Przyjdź!”, skierowane do tego, kto słyszy, jest zatem również wołaniem o sąd i sprawiedliwość na ziemi $(16,5-6 ; 19,11)$, o należną odpłatę $(2,23 ; 22,12)$. Jej gwarantem pozostaje Chrystus - Prawdziwy i Wierny $(16,5)$, Baranek, co jest lampa dla narodów (21,23-24), Odroślą i Potomstwem Dawida, Gwiazdą poranną $(22,16)$, która wschodzi z Jakuba (Lb 24,17; Iz 11,1.10) dla Kościoła jako swej Oblubienicy. Jej zgodne wołanie wraz z Duchem Świętym ${ }^{86}$ o przyjście Jezusa ma pobudzać wierzących do podobnej prośby, ale zarazem skłaniać błądzących i nieprzekonanych do przyjęcia niezmiennego, wiarygodnego proroctwa (22,18-19), które Jan zapisał zgodnie z otrzymanym od Chrystusa poleceniem $(1,11 ; 21,5)$.

W odróżnieniu od poprzednich pozytywnych wyobrażeń kobiecych figur w Apokalipsie, wzmianka z epilogu pozbawiona jest komentarza do wyglądu Oblubienicy. Milczenie wizjonera w tym względzie można uzasadnić tym, że jej zewnętrzną charakterystykę wyczerpują wcześniejsze opisy, związane z wizjami Niewiasty obleczonej w słońce (Ap 12,1-18) i Nowego Jeruzalem jako personifikowanej Oblubienicy Baranka $(21,1-22,5)$. Taki zabieg odpowiada semickiemu sposobowi przedstawiania rzeczywistości w różnych jej wymiarach. W tym konkretnym przypadku mowa o jednym Kościele - z jednej strony pokutującym i cierpiącym na ziemi, a z drugiej żyjącym w chwale nieba - który łączy kobiety i mężczyzn, wyrażających to samo pragnienie Bożego panowania nad całym stworzeniem ${ }^{87}$.

86 O Duchu Świętym, który w Ap 22,17 woła wraz Kościołem piszą: G.K. Beale, The Book of Revelation, 1148; B.K. Blount, Revelation, 412; C. Doglio, Apocalisse, 215 czy D. Ledwoń, Apokalipsa, 177. Natomiast W.J. Harrington (Revelation, 223) wskazuje na Ducha Jezusa inspirującego proroków. Z kolei o duchu w znaczeniu natchnienia prorockiego traktują w swoich komentarzach także D.E. Aune (Revelation 17-22, 1229) i Wojciechowski (Apokalipsa, 398). Zaś G.R. Osborne (Revelation, 793) przypomina, że źródłem natchnienia jest Duch.

87 Słusznie L.L. Sechrest („Antitypes”, 118) sprzeciwia się bezpodstawnemu twierdzeniu T. Pippin, że w świetle Apokalipsy, choć Nowe Jeruzalem jest kobietą, 


\section{Znaczenie kobiecych obrazów w Apokalipsie}

O doniosłej roli kobiecych wyobrażeń w proroctwie Jana świadczy ich ścisły związek z kluczowymi tematami apokaliptycznego przesłania, do których należy zaliczyć: misterium Boga Jedynego, objawianego przez Syna w Duchu Świętym ${ }^{88}$, eklezjologię, etykę chrześcijańskiego życia, politykę, wreszcie soteriologię i eschatologię̨ ${ }^{89}$. Z kolei na literacką i teologiczną kompozycję wspomnianych obrazów składa się bogaty zespół głównie starotestamentowych, ale też pozabiblijnych odniesień. Są nimi aluzje do wydarzeń zbawczych z dziejów Izraela oraz echa interpretujących je prorockich przepowiedni. Odwołują się one wprost do małżeńskiej metaforyki czy kobiecej symboliki i pośrednio czerpią z utrwalonych w kulturze helleńskiej mitycznych podań (jak mit o Latonie czy opiekuńczej roli kobiecych bóstw względem miast), które Jan oryginalnie przetwarza, by oddawały rzeczywistą kondycję Kościoła w starciu z upostaciowionym złem. Dlatego przywołane w Apokalipsie sugestywne sylwetki kobiet (realistyczne i symboliczne) posiadają tożsamość zwodzicielki wierzących lub Oblubienicy Baranka; idealnej Małżonki albo porzuconej przez wszystkich Wielkiej Prostytutki i wdowy; matki żyjących lub matki nierządnic. Ich duchowe profile odzwierciedla zewnętrzny wygląd postaci (lśniące lub szkarłatne szaty, drogocenne ozdoby, atrybuty boskości oraz królewskiej godności), przeciwna Bogu postawa lub zbudowana na dozgonnej wierności oblubieńcza z Nim relacja; wyrażony w zstępowaniu od Boga status zwyciężczyni lub świadcząca o potępieniu kara zatopienia gorszycielki w morzu. Profetyczna wizja Jana ma na uwadze zarówno biblijne symbole miast-dziewic, Izraela-oblubienicy i narodów-niewiast z ich cnotami i wadami, jak też rozpoznawalny w kulturze helleńskiej zwyczaj identyfikowania ośrodków miejskich z ich patronkami. W utrwalonych przez Jana obrazach kobiet odbija się zatem nie tyle przeznaczenie i los

to nie wliczają się do niego kobiety - najpierw zmarginalizowane, a następnie wykluczone z przyszłego Bożego świata, co miałoby odpowiadać męskiej fantazji politycznej. Zob. T. Pippin, „Eros and the End”, 195.

${ }_{88}$ Zdaniem R. Bauckham (The Theology of the Book of Revelation, 24) obecne w Apokalipsie formuły trynitarne świadczą o tym, że „Jan dokonał twórczej refleksji nad chrześcijańskim rozumieniem boskości”.

89 Por. M. Wojciechowski, Apokalipsa, 79-90. 
jednostek, ile całych wspólnot, wezwanych do oblubieńczej relacji z Bogiem i Barankiem.

Teologiczna interpretacja dziejów świata, której wizjoner z Patmos dokonuje za pomocą figur literackich oraz znanych motywów w postaci głosu oblubienicy, włosów, dziewictwa, wdowieństwa, nierządu czy małżeństwa, czyni jego proroctwo uniwersalnym. Podjęta w nim wyrazista polemika chrystocentrycznej idei zbawienia z pogaństwem nie służy - jak mniemają przedstawiciele radykalnej teologii feministycznej - utrwalaniu stereotypów ani patriarchalnego systemu, który czyni kobiety ofiarami przemocy ${ }^{90}$. Przesłanie Jana po prostu wykorzystuje i przejaskrawia realia epoki. Przedstawione w Apokalipsie postacie zachowują swoją podmiotowość i należą do głównych bohaterów narracji, zajmując ważne miejsca po obu stronach eschatologicznego konfliktu. W kontekście nieuprawnionych oskarżeń tekstu o mizoginizm, trzeba wyraźnie zaznaczyć, że wydarzeniem kluczowym dla zmiany niesprawiedliwych relacji społecznych, o którym mowa w Janowym widzeniu, jest ofiara z życia Baranka. Ponieważ Jego krew nabywa Bogu ludzi - bez względu na ich płeć - z każdego pokolenia, języka ludu i narodu (Ap 5,9.12), to na tle wydarzeń czasów Starego Testamentu dokonane przez Chrystusa dzieło zbawienia ma przede wszystkim charakter unikalny ${ }^{91}$. Ani dana przez Boga Abrahamowi obietnica błogosławieństwa dla innych narodów ( $\mathrm{Rdz} 12,2-3)$ czy niezmiernie licznego potomstwa $(\mathrm{Rdz}$ 13,16; 15,5; Hbr 6,14), ani usprawiedliwienie wielu przez cierpienia Sługi Jahwe (Iz 53,11) nie prowadzą do oczyszczenia z win Izraela, a tym mniej obcych narodów, jak dzieje się to za sprawą Jezusa (Ap 1,5). Także zawarta w proroctwie Ezechiela wizja nowej świątyni $(40,1-43,17 ; 46,19-47,12)$ i zamieszkania Boga pośród swego ludu

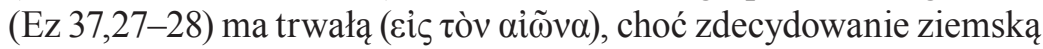
perspektywę, podczas gdy objawienie dane Janowi skupia uwagę jego adresatów na wizji niebieskiego Jeruzalem $(21,10 b-22,5)$. Nie ma w niej miejsca dla splamionej grzechem ziemi ani nieba (Ap 21,1;

90 Zob. T. Pippin, Death and Desire, 80.

91 S.R. Smolarz (Covenant and the Metaphor, 335) przyrównuje dzieło zbawienia do moharu, który narzeczony obowiązkowo uiszczał ojcu dziewczyny, by móc ją pojąć za żonę (zob. Rdz 34,12; Wj 22,16; 1 Sm 18,25). 
por. Iz 65,17), które byłoby ich świadkiem. Także zniknięcie morza $(21,1)$, jako symbolu prześladowań Bożego ludu (Ap 21,4) ${ }^{92}$, wskazuje na głęboką przemianę świata, w którym królowała Wielka Nierządnica (17,3). Demoniczny obraz jej wyglądu i zachowań odzwierciedla opierający się na przemocy i wyzysku stary, „nierządny” porządek świata ${ }^{93}$. Warto zauważyć, że w świetle Janowej Apokalipsy zarówno fałszywa prorokini Jezabel, jak i upersonifikowana Babilonia nie są ofiarami wspomnianego systemu zła, lecz aktywnie uczestniczą w jego utrwalaniu. Surowa krytyka ich postępowania, a następnie wymierzona im przez Boga dotkliwa kara, czynią jedynie zadość długo oczekiwanej sprawiedliwości ${ }^{94}$, której w Apokalipsie domaga się prześladowany na ziemi Kościół męczenników (Ap 6,10; por. Ps 104[103],35).

Jego obrazem jest zwalczana przez ognistego smoka Niewiasta. Wygląd Matki Mesjasza w istocie świadczy nie tylko o jej włączeniu przez Boga w plan zbawienia, ale stanowi także zapowiedź jej udziału w przyszłej chwale, którą odsłania wizja Nowego Jeruzalem jako zstępującej od Boga Małżonki Baranka (Ap 21,2). Wszystkie dramatyczne i katastroficzne wydarzenia Apokalipsy prowadzą ostatecznie do objawienia zwycięstwa łaski Boga i wydobycia na światło dzienne prawdy o człowieku - ukazania godnego czci świadectwa wierności i sprawiedliwości albo zasługującego na potępienie kłamstwa (czyli fałszywej doktryny) ${ }^{95}$ i obrzydliwości $(22,11)$. Wizja Świętego Miasta przygotowanego jak Oblubienica dla męża $(21,2)$ sugeruje pewien proces jej dążenia do doskonałości i takiego współdziałania z Bogiem, które zasługuje na otrzymanie weselnego i królewskiego zarazem odzienia z lśniąco czystego bisioru, jak lśniące jest oblicze Boga (Ps 104[103],2), Syna Człowieczego (Ap 1,13-16; 22,16) czy aniołów $(15,6)$. Nazwana Małżonką Baranka święta społeczność niebieskiego Jeruzalem jest obrazem idealnej pomocy dla Męża (Ap 2,20.23)

92 Por. G.K. Beale, The Book of Revelation, 1042.

93 Zdaniem A.Y. Collins („Feminine Symbolism”,129) zarówno przemoc, jak i męska perspektywa przedstawionych w Ap 17 wydarzeń wynikają z faktu, że okrucieństwo wojen wiązało się w starożytności (jak i współcześnie) z przemocą wobec kobiet, a kobieca symbolika służyła wyrażaniu degradacji.

94 Por. B. Urbanek, „Metafory gniewu Bożego”, 261-262.

95 Por. H. Witczyk, „Eklezjologia”, 216. 
i zarazem doskonałym antytypem biblijnej Ewy, prawdziwą matką żyjących, uosobieniem wszystkich cnót i zalet, a przez to godnym Boga miejscem Jego zamieszkania z ludźmi (Ap 21,3).

Nie może zatem dziwić, że wyrażeniu doskonałej jedności Chrystusa z Kościołem służy bardzo droga autorom biblijnym metafora małżeńska, która w Apokalipsie Jana osiąga swój najgłębszy sens ${ }^{96}$ i to co najmniej z trzech powodów. Po pierwsze, wykracza ona jednoznacznie poza ziemskie ramy egzystencji jednego narodu ${ }^{97}$. Po drugie, wspomniana metafora i związana z nią kobieca symbolika dotyczą wspólnoty Baranka, która mając chwałę od Boga $(21,11)$, jest aktywnym podmiotem eschatologicznych godów weselnych. Wreszcie po trzecie, oblubieńcza relacja wspólnoty zbawionych z Bogiem ma charakter trynitarny i eklezjalny. Ukazuje ona Stwórcę w nieznanej starotestamentowemu objawieniu tajemnicy życia Ojca, Syna i Ducha Świętego - Boga, którego czystą Oblubienicą jest Kościół. Jego obraz, utrwalony w Apokalipsie za pomocą Niewiasty obleczonej w słońce oraz uosobionego Jeruzalem jako Małżonki Baranka, wyraźnie dominuje w wielowątkowym widzeniu Jana i wyraźnie odróżnia je od proroctw dotyczących biblijnego Izraela. Pomiędzy silnie skontrastowanymi w Apokalipsie obrazami kobiet, które są w niej głównymi nośnikami teologii, nie zachodzi równowaga. W ostatniej księdze chrześcijańskiej Biblii ich pozytywne wyobrażenia przeważają nad negatywnymi, ale jedne i drugie ukazują szerokie spektrum relacji Boga z ludźmi, potęgę dobra i zgubne skutki oddziaływania zła, naturę Kościoła i świata, a także celowość historii i zachodzących w niej wydarzeń. Bez kobiecej symboliki i związanych z nimi figur nie byłoby zrozumiałe orędzie Jana o bezgranicznej i wiernej miłości Boga, który swoje dzieci, zebrane przez Chrystusa w jeden święty Kościół, pośród trudów doczesności, prowadzi do obiecanego życia wiecznego.

96 Por. U. Vanni, L'uomo dell'Apocalisse, 138.

97 W Starym Testamencie wizję pełnej wesela uczty o wyraźnie uniwersalnym charakterze przedstawia Iz 25,6-9. Jej miejscem nie jest jednak pełne obecności Boga niebo ani nowe Jeruzalem, ale zlokalizowana w ziemi Izraela góra Syjon. 
Jan z Patmos, zainspirowany popularnymi motywami z tradycji biblijnej i świata grecko-rzymskiego, stworzył w swoim profetycznym dziele oryginalne obrazy kobiecych postaci. Należą one do głównych bohaterów Apokalipsy. Występujące w niej realistyczno-symboliczne i symboliczne odwołania do kobiet odpowiadają czarno-białej wizji świata, a obecne w nim bohaterki znajdują się po przeciwnych stronach eschatologicznego konfliktu dobra ze złem, odgrywając w Apokalipsie pozytywne lub negatywne role ${ }^{98}$. Ich silnie skontrastowane obrazy spełniają dwojaką funkcję perswazyjną. Z jednej strony służą wyrażeniu moralnej kondycji reprezentowanych przez nie społeczności (sług Boga i Baranka lub pozostających w mocy Szatana), z drugiej zaś skłaniają adresatów Janowego proroctwa do pozytywnej odpowiedzi na złożone w nim świadectwo wiary i odparcia duchowych zagrożeń. Fakt, że status wierzących w Chrystusa oraz ich przeznaczenie należy odczytywać w kluczu małżeńskiej metafory świadczy jednoznacznie o doniosłej roli kobiet w życiu chrześcijańskiej wspólnoty, która jako udoskonalona dzięki krwi Baranka Jego Oblubienica, staje się ostatecznie obrazem wypełnionej nadziei zbawienia. Można więc śmiało powiedzieć, że Jan przełamuje kulturowe stereotypy. Wykreowane przez niego literacko i teologicznie kobiece figury tworzą nie tylko obraz dobrej lub złej kobiety, matki, narodu czy miasta, ale wielkiej cywilizacji życia lub śmierci, zbawienia lub potępienia. Gdy na początku dziejów świata i zbawienia kobieta jako współwinna upadku ludzkości zostaje wygnana z raju, rodzi do życia obarczonego cierpieniem i śmiercią, zaś w czasach ostatecznych jej złożony antytyp staje się współpracownicą w dziele zbawienia, matką wiecznie żyjących, niespotykanie piękną Oblubienicą Boga i Baranka.

98 Por. H. Stenström, ,They have not defiled themselves with women”, 35. 


\title{
The Images, Roles and Significance of Women in the Book of Revelation
}

\begin{abstract}
Women are amongst the main protagonists of the book of Revelation. Their images, functions, and significance in the text of the visionary seer from Patmos are the subject of this synchronic study. The author points to the fact that the horizon of exegetical inquiries used in the book of Revelation, apart from the nouns yuvń (woman, wife) and vú $\mu \varphi \eta$ (bride), is broadened by the use of juxtaposed elements of feminine symbolism and nuptial imagery. John has endowed popular themes from the intersection of Judaism and the Greco-Roman world with new meanings. They contribute to the image of the personified Church, which fights against personified evil and triumphs as the Bride of the Lamb.
\end{abstract}

Keywords: Book of Revelation, metaphor, symbolism, women, image, gender studies, feminist theology

\section{Bibliografia}

Atwood, M., The Edible Woman, New York (NY) 1984.

Aune, D.E., Revelation 1-5 (WBC 52 A), Dallas (TX) 1997.

Aune, D.E., Revelation 6-16 (WBC 52 B), Nashville (TN) 1998.

Aune, D.E., Revelation 17-22 (WBC 52 C), Nashville (TN) 1998.

Aune, D.E., ,St. John's Portrait of the Church in the Apocalypse”, Evangelical Quarterly 38 (1966), 131-149.

Barr, D.L., „Towards an Ethical Reading of The Apocalypse: Reflections on John's Use of Power, Violence, and Misogyny", Society of Biblical Literature 1997 Seminar Papers (SBLSP 36), Atlanta (GA) 1997, 358-373.

Bauckham, R., The Theology of the Book of Revelation, Cambridge-New York 1993.

Beale, G.K., The Book of Revelation. A Commentary On the Greek Text, Grand Rapids (MI) 1999.

Bednarz, M., „Niewiasta obleczona w Słońce”, Resovia Sacra. Studia Teologiczno-Filozoficzne Diecezji Rzeszowskiej 14-15 (2007/2008) 23-42.

Benedykt XVI, Posynodalna adhortacja apostolska Verbum Domini o słowie Bożym w życiu i misji Kościoła (30 września 2010), Katowice 2010.

Biguzzi, G., „Is the Babylon of Revelation Rome or Jerusalem?”, Biblica 87 (2006), 371-386.

Blount, B.K., Revelation. A Commentary, Louisville (KY) 2013.

Boring, M.E., Apocalisse, tłum. F. Ronchi (SC 43), Torino 2008.

Boring, M.E., „Narrative Christology in the Apocalypse”, Catholic Biblical Quarterly 54 (1992) nr 4, 702-723.

Bruns, J.E., „The Contrasted Women of Apocalypse 12 and 17”, Catholic Biblical Quarterly 26 (1964) nr 4, 459-463.

Bullinger, E.W., Figures of Speech Used in the Bible, London-New York 1898. 
Castelli, E., Imitating Paul: A Discourse of Power, Louisville (KY) 1991.

Charles, R.H., A Critical and Exegetical Commentary on Revelation of St. John: With Introduction, Notes, and Indices also the Greek Text and English Translation, Edinburgh 1971.

Chmiel, J., „Model kobiety w Biblii. Zarys hermeneutyczny”, Ruch Biblijny i Liturgiczny 48 (1995) nr 4, 255-259.

Collins, A.Y., The Combat Myth in the Book of Revelation (HDR 9), Missoula (MT) 1976.

Collins, A.Y., Crisis and Catharsis: The Power of the Apocalypse, Philadelphia (PA) 1984.

Collins, A.Y., „Feminine Symbolism in the Book of Revelation”, w: A.-J. Levine, M.M. Robbins (red.), Feminist Companion to the Apocalypse of John, London-New York 2009, 121-130.

Collins, A.Y., „Persecution and Vengeance in the Book of Revelation”, w: D. Hellholm (red.) Apocalypticism in the Mediterranean World and the Near East: Proceedings of the International Colloquium on Apocalypticism, Uppsala 1979, Tübingen 1983, 729-748.

Częsz, B., „Maryja w nauczaniu św. Ireneusza z Lyonu”, Salvatoris Mater 11 (2009) nr 2, 70-85.

Doglio, C., Apocalisse di Giovanni. Introduzione e commento, wyd. 2, Padova 2014.

Du Rand, J.A., ,The New Jerusalem as Pinnacle of Salvation: Text (Rev 21:122:5) and Intertext", Neotestamentica 38 (2004) nr 2, 275-302.

Duvall, J.S., The Heart of Revelation. Understanding the 10 Essential Themes of the Bible's Final Book, Grand Rapids (MI) 2016.

Dyer, C.H., „The Identity of Babylon in Revelation 17-18 (Part 2)”, Bibliotheca Sacra 144 (1987), 433-449.

Fanning, B. M., Revelation (ZECNT 20), Grand Rapids (MI) 2020.

Fekkes III, J. „«His Bride Has Prepared Herself»: Revelation 19-21 and Isaian Nuptial Imagery", Journal of Biblical Literature 109 (1990) nr 2, 269-287. Fontenrose, J.E., Python: A Study of Delphic Myth and Its Origins, New York (NY) 1974.

Hamori, E.J., Women's Divination in Biblical Literature: Prophecy, Necromancy, and Other Arts of Knowledge, New Haven-London 2015.

Harrington, W.J., Revelation (SP16), Collegeville (PA) 1993.

Huber, L. R., Like a Bride Adorned. Reading Metaphor in John's Apocalypse, New York (NY) 2007.

Hylen, S.E., „Metaphor Matters: Violence and Ethics in Revelation”, Catholic Biblical Quarterly 73 (2011) nr 4, 777-796.

Ipsen, A., Sex Working and the Bible, London-New York 2009.

Ireneusz z Lyonu, Adversus haereses, J. Brylowski (tłum.), Pelplin 2018. 
Jan Paweł II, Encyklika Redemptoris Mater o błogosławionej Maryi Dziewicy w życiu pielgrzymującego Kościoła (25 marca 1987), w: Encykliki Ojca świętego Jana Pawła II, Kraków 2005, 353-431.

Johnson-DeBaufre, M., „Texts and Readers, Rhetorics and Ethics”, w: E. Schüssler Fiorenza (red.), Feminist Biblical Studies in the Twentieth Century: Scholarship and Movement (BW 9.1), Atlanta (GA) 2014, 217-231. Justyn Męczennik, 1 i 2 Apologia: Dialog z Żydem Tryfonem, L. Misiarczyk (tłum. i oprac.), Warszawa 2012.

Karczewski, M., Reinterpretacja Księgi Rodzaju w Apokalipsie św. Jana, Olsztyn 2010.

Koester, C.R., Revelation: A New Translation with Introduction and Commentary (AB 38), New Haven (CT) 2014.

Kotecki, D., Jezus a Bóg Izraela w Apokalipsie Św. Jana (STT 27), Toruń 2013.

Le Frois, B.J. The Woman Clothed with the Sun (Apoc 12). Individual or Collective? An Exegetical Study, Rome 1954.

Ledwoń, D., Apokalipsa Świętego Jana. Wstęp, przekład z oryginatu, komentarz, Katowice 2019.

Levine, A.-J., Robbins, M.M. (red.), Feminist Companion to the Apocalypse of John, London-New York 2009.

Mastalska, D., „Maryja spełnieniem miłości Ojca odrzuconej przez Ewę”, Salvatoris Mater 1 (1999) nr 1, 58-76.

Miller, K.E., „The Nuptial Eschatology of Revelation 19-22”, Catholic Biblical Quarterly 60 (1998) nr 2, 301-318.

Moore, S.D., Untold Tales from the Book of Revelation: Sex and Gender, Empire and Ecology (RBSt 79), Atlanta (GA) 2014.

Morris, L., The Book of Revelation. An Introduction and Commentary (TNTC), wyd. 2, Leicester 1987.

Mounce, R.H., The Book of Revelation, Grand Rapids 1977.

Neufeld, D., „Under the Cover of Clothing: Scripted Clothing Performances in the Apocalypse of John", Biblical Theology Bulletin: Journal of Bible and Culture 35 (2005), 67-76.

Nowakowski, P., „Kobiecy symbol apokaliptyczny w reformatorskiej interpretacji - Wielka Nierządnica i Výklad na Zjevenie svatého Jana Jakoubka ze Stř́bra", w: W. Iwańczak, J. Smołucha (red.), Świat kobiet w Czechach $i$ w Polsce w średniowieczu i epoce nowożytnej, Kraków 2018, 399-412.

Økland, J., , «In publicum procurrendi»: Women in the public Space of Roman Greece", w: L. Larsson Lovén, A. Strömberg (eds), Aspects of Women in Antiquity: Proceeding of the First Nordic Symposium on Women's Lives in Antiquity. Göteborg 12 - 15 June 1997, Jonsered 1998, 127-139.

Osborne, G.R., Revelation, Grand Rapids (MI) 2002.

Pataki, A.D., „A Non-combat Myth in Revelation 12”, New Testament Studies 57 (2011) nr 2, 258-272. 
Pedroli, L., Dal fidanzamento alla nuzialità escatologica. La dimensione antropologica del rapporto crescente tra Cristo e la Chiesa nell'Apocalisse, wyd. 2, Assisi 2015.

Pedroli, L., „Le «Lettere alle sette Chiese» (Ap 1,9-3,22): trama di un fidanzamento in atto", Studia Koszalińsko-Kołobrzeskie 21 (2014), 87-101.

Pippin, T., Apocalyptic Bodies: The Biblical End of the World in Text and Image, London-New York 1999.

Pippin, T., Death and Desire: The Rhetoric of Gender in the Apocalypse of John, Louisville 1992.

Pippin, T., „Eros and the End: Reading for Gender in the Apocalypse of John”, Semeia 59 (1992), 193-210.

Pippin, T., ,Jezebel Re-Vamped”, Semeia 69-70 (1995), 221-233.

Pippin, T., Clark, J.M., „Revelation/Apocalypse”, w: D. Guest, T. Bohache (red.), The Queer Bible Commentary, London 2006, 753-768.

Popielewski, W., Alleluja! Liturgia godów Baranka eschatologicznym zwycięstwem Boga (Ap 19,1-8), Kielce 2001.

Prigent, P., Apocalypse 12. Histoire de l'exégèse (BGBE 2), Tübingen 1959.

Quodvuldetus, De symbolo III, w: R. Braun (tłum.), Opera Quodvultdeo Carthaginiensi episcopo tributa, Turnholti 1976, 349-363.

Resseguie, J.L., The Revelation of John. A Narrative Commentary, Grand Rapids (MI) 2009.

Rocha, A.V., „Entre la fragilidad y el poder: Mujeres en al Apocalipsis”, Revista de Interpretación Bíblica Latinoamericana 48 (2004), 95-104.

Rosik, M., „Mariologia”, w: M. Rosik (red.), Teologia Nowego Testamentu, t. II: Dzieło Janowe, Wrocław 2008, 265-293.

Rossing, B.R., The Choice Between Two Cities: Whore, Bride, and Empire in the Apocalypse (HTS 48), Harrisburg (PA) 1999.

Sechrest, L.L., „Antitypes, Stereotypes, and Antetypes. Jezebel, The Sun Woman, and Contemporary Black Women", w: G.L. Byron, V. Lovelace (red.), Womanist Interpretations of the Bible. Expanding the Discourse (SemeiaSt 85), Atlanta (GA) 2016, 113-137.

Selvidge, M.J., „Powerful and Powerless Women in the Apocalypse”, Neotestamentica 26 (1992), 157-167.

Selvidge, M.J., „Reflections on Violence and Pornography: Misogyny in the Apocalypse and Ancient Hebrew Prophecy", w: A. Brenner (red.), A Feminist Companion to the Hebrew Bible in the New Testament, Sheffield 1996, 274-285.

Shea, W.H., „The Parallel Literary Structure of Revelation 12 and 20”, Andrews University Seminary Studies 23 (1985) nr 1, 37-54.

Smalley, S.S., The Revelation to John: A Commentary on the Greek Text of the Apocalypse, Downers Grove (IL) 2015. 
Smolarz, S.R., Covenant and the Metaphor of Divine Marriage in Biblical Thought. A Study With Special Reference to the Book of Revelation, Eugene 2011. Stefaniak, L., Interpretacja 12 rozdziału Apokalipsy św. Jana w świetle historii egzegezy, Poznań 1957.

Stefaniak, L., „«Mulier amicta sole» (Apok 12,1-17) w świetle współczesnej egzegezy biblijnej", Ruch Biblijny i Liturgiczny 9 (1956), 262-283.

Stenström, H., „'They have not defiled themselves with women...' Christian Identity According to the Book of Revelation", w: A.-J. Levine, M.M. Robbins, (red.), Feminist Companion to the Apocalypse of John, London-New York 2009, 33-54.

Streete, G.C., The Strange Woman: Power and Sex in the Bible, Louisville (KY) 1997.

Tamez, E. „Feminist Biblical Studies in Latin America and the Caribbean”, w: E. Schüssler Fiorenza (red.), Feminist Biblical Studies in the Twentieth Century: Scholarship and Movement (B\&W 9.1), Atlanta (GA) 2014, 35-52.

Tenney, M.C., Interpreting Revelation, Grand Rapids (MI) 1957.

Thimmes, P., „'Teaching and Beguiling My Servants': The Letter to Thyatira (Rev. 2.18-29)", w: A.-J. Levine, M.M. Robbins (red.), Feminist Companion to the Apocalypse of John, London-New York 2009, 69-87.

Thimmes, P., „Women Reading Women in the Apocalypse: Reading Scenario 1, the Letter to Thyatira (Rev. 2.18-29)", Currents in Biblical Research 2 (2003) $\mathrm{nr} 1,128-144$.

Thomas, R.L., Revelation 8-22: An Exegetical Commentary, Chicago (IL) 1995. Tyloch, W., „Religie Fenicji i Syrii”, w: J. Keller, B. Kupis (red.), Religie Bliskiego Wschodu i dawnej Europy: zarys dziejów, Warszawa 1981, 119-132.

Urbanek, B., Apokalipsa. Szczęśliwy, kto ją odczytuje, Częstochowa 2012.

Urbanek, B., „Metafory gniewu Bożego w Janowej Apokalipsie”, Verbum Vitae 33 (2018), 251-276.

Vander Stichele, C., „Re-membering the Whore: The Fate of Babylon According to Revelation 17.16", w: A.-J. Levine, M.M. Robbins (red.), Feminist Companion to the Apocalypse of John, London-New York 2009, 106-120. Vanni, U., Apocalisse, libro della Rivelazione: Esegesi biblico-teologica e implicazioni pastorali, Bologna 2009.

Vanni, U., L'uomo dell'Apocalisse, Roma 2008.

Villiers, P.G.R. de, „The Violence of Nonviolence in the Revelation of John”, Open Theology 1 (2015), 189-203.

Witaszek, G., „Jerozolima: córka Syjonu a Maryja”, Salvatoris Mater 1 (1999) nr 2, 46-63.

Witczyk, H., „Eklezjologia”, w: M. Rosik (red.), Teologia Nowego Testamentu, t. II: Dzieło Janowe, Wrocław 2008, 159-217. 
Wojciechowski, M., Apokalipsa świętego Jana. Objawienie, a nie tajemnica. Wstęp - przektad z oryginatu - komentarz (NKB.NT XX), Częstochowa 2012.

Wojciechowski, M., „Wpływy greckie w Apokalipsie św. Jana”, Biblica et Patristica Thoruniensia 5 (2012), 115-124.

Wojciechowski, M., Wplywy greckie w Biblii, Kraków 2012.

Wood, H.J., „Gender Inequality: The Problem of Harmful, Patriarchal, Traditional and Cultural Gender", HTS Teologiese Studies/Theological Studies 75 (2019) nr 1, 1-8. 